\title{
Use of digestate from a decentralized on-farm biogas plant as fertilizer in soils: An ecotoxicological study for future indicators in risk and life cycle assessment
}

Pivato, Alberto; Vanin, Stefano; Raga, Roberto; Lavagnolo, Maria Cristina; Barausse, Alberto; Rieple, Antonia; Laurent, Alexis; Cossu, Raffaello

Published in:

Waste Management

Link to article, DOI:

10.1016/j.wasman.2015.12.009

Publication date:

2016

Document Version

Peer reviewed version

Link back to DTU Orbit

Citation $(A P A)$ :

Pivato, A., Vanin, S., Raga, R., Lavagnolo, M. C., Barausse, A., Rieple, A., Laurent, A., \& Cossu, R. (2016). Use of digestate from a decentralized on-farm biogas plant as fertilizer in soils: An ecotoxicological study for future indicators in risk and life cycle assessment. Waste Management, 49, 387-389.

https://doi.org/10.1016/j.wasman.2015.12.009

\section{General rights}

Copyright and moral rights for the publications made accessible in the public portal are retained by the authors and/or other copyright owners and it is a condition of accessing publications that users recognise and abide by the legal requirements associated with these rights.

- Users may download and print one copy of any publication from the public portal for the purpose of private study or research.

- You may not further distribute the material or use it for any profit-making activity or commercial gain

- You may freely distribute the URL identifying the publication in the public portal 


\section{Use of digestate from a decentralized on-farm biogas plant as fertilizer in soils: an ecotoxicological study for future indicators in risk and life cycle assessment}

Alberto Pivato $^{(1)^{*}}$, Stefano Vanin ${ }^{(2)}$, Roberto Raga ${ }^{(1)}$, Maria Cristina Lavagnolo ${ }^{(1)}$, Alberto Barausse $^{(1)}$, Antonia Rieple ${ }^{(1)}$, Alexis Laurent ${ }^{(3)}$, Raffaello Cossu ${ }^{(1)}$

${ }^{(1)}$ DII - Department of Industrial Engineering, University of Padova, via Marzolo $n$ 9, 35131 Padova, Italy.

${ }^{(2)}$ Department of Biological Sciences, School of Applied Sciences, University of Huddersfield, Queensgate, Huddersfield HD1 3DH, UK.

(3) Division for Quantitative Sustainability Assessment, Department of Management Engineering, Technical University of Denmark (DTU). 2800 Kgs. Lyngby - Denmark.

*Corresponding author

Alberto Pivato

Tel.: +390498278987; Fax: +390498278984

Email: alberto.pivato@unipd.it

Keywords: Digestate ; ecotoxicity tests; risk assessment; life cycle assessment 
Pivato A., Vanin S., Raga R., Lavagnolo M.C., Barausse A., Rieple A., Laurent A., Cossu R. 2016. Use of digestate from a decentralized on-farm biogas plant as fertilizer in soils: An ecotoxicological study for future indicators in risk and life cycle assessment. Waste Management 49, 378-389. http://dx.doi.org/10.1016/j.wasman.2015.12.009.

\section{ABSTRACT}

Over the last decade, the number of decentralized farm biogas plants has increased significantly in the EU. This development leads not only to an increasing amount of biogas produced, but also to a higher amount of digestate obtained.

One of the most attractive options to manage the digestate is to apply it as biofertiliser to the soil, because this gives the opportunity of recovering the nutrients, primarily nitrogen and phosphorus, and of attenuating the loss of organic matter suffered by soils under agricultural exploitation.

Studies have claimed that digestates can present a residual biodegradability, and contain complex organic elements, salts or pathogenic bacteria that can damage terrestrial organisms. However few ecotoxicological studies have been performed to evaluate the ecological impact of digestate application on soil.

In this study, the use of digestate as biofertiliser in agriculture was assessed by a battery of ecotoxicological tests considering the potential pollutants present in the digestate as a whole by using the "matrix-based" approach (also known as "whole effluent toxicity" for eluates or wastewater effluents). The direct and indirect tests included plant bioassays with Lepidium sativum, earthworm bioassays with Eisenia fetida, aquatic organisms (Artemia sp. and Daphnia magna) and luminescent bacteria bioassays (Vibrio fischeri).

Direct tests occurred to be more sensitive than indirect tests. The earthworm bioassays did not show serious negative effects for concentrations up to $15 \%$ (dry weight/ dry weight percent, $\mathrm{w} / \mathrm{w} \mathrm{dm}$ ) and the plant bioassays showed no negative effect, but rather a positive one for concentrations lower than $20 \%(\mathrm{w} / \mathrm{w} \mathrm{dm})$, which encourages the use of digestate as a biofertiliser in agriculture provided that proper concentrations are used. The indirect tests, on the eluate, with the using aquatic organisms and luminescent bacteria showed an LC50 value of $13.61 \%$ volume/volume percent, v/v) for Daphnia magna and no toxicity for Artemia sp. and Vibrio fischeri.

The ecotoxicological parameters obtained from the experimental activity have been analyzed so that they could serve in both ecological risk assessment (ERA) and life cycle assessment (LCA) to assess the risks and impacts of using digestate as a biofertiliser in agriculture. An interim effect factor of $1.17 \mathrm{E}-3 \mathrm{~m}^{3} / \mathrm{kg}$-in-soil is advocated and can be used in life cycle impact assessment modelling of terrestrial ecotoxicity. A predicted non effect concentration for soil organisms was defined at $341 \mathrm{mg}$-digestate/kg-soil and can be used for the doseresponse assessment step in ERA. Although these values are recommended for use in ERA and LCA applications, it should be stressed that they underlie important uncertainties, which should be reduced by increasing the number of toxicological tests, in particular of chronic studies conducted at different trophic levels. 
Pivato A., Vanin S., Raga R., Lavagnolo M.C., Barausse A., Rieple A., Laurent A., Cossu R. 2016. Use of digestate from a decentralized on-farm biogas plant as fertilizer in soils: An ecotoxicological study for future indicators in risk and life cycle assessment. Waste Management 49, 378-389. http://dx.doi.org/10.1016/j.wasman.2015.12.009.

\section{$1 \quad$ INTRODUCTION}

Over the last decade, the number of biogas plants in the EU has increased significantly. The primary energy production grew by 15.7 \% in 2012 compared to 2011 (EurObserv'ER 2013) and in the upcoming years it is still expected to grow further due to the 2020 renewable energy targets of the European Union.

Purpose-designed energy recovery plants, which include decentralized farm biogas plants, centralized digesters, multiproduct plants and solid waste methanation plants dominate the biogas production (66.5 \% in 2012) (EurObserv'ER 2013). Especially the field of multiproduct plants, i.e. plants which can produce different products according to the requests of the market, has the potential to grow (Rauch 1998). This is due to the fact that biogas plants merged with other energy processes, like oil extraction from microalgae (Tercero et al., 2014), which makes multiproduct plants an attractive option for a convenient contribution to the overall energy balance and the design and planning of feasible and sustainable energy systems (Ortiz-Gutiérrez et al., 2013).

The remaining fraction of biogas production is represented by landfill biogas and biogas from sewage plants (EurObserv’ER 2013).

The recent development in the biogas sector leads not only to an increasing amount of biogas produced, but also to a higher amount of digestate obtained. Europe thus generates about 80 million tons of digestate per year, from ca. 13,000 biogas facilities (Fachverband Biogas / EBA / BiPRO 2013).

Decentralized farm biogas plants usually co-digest animal manure and slurry from only one farm and can apply pre- and post-treatments as well as separation technologies (Holm-Nielsen et al., 2009).

According to Gómez et al. (2005), one of the most attractive options in terms of reducing environmental issues, is to apply digestate as biofertiliser to the soil, because it allows recovering the nutrients, primarily nitrogen and phosphorus, and limiting the loss of organic matter suffered by soils under agricultural exploitation. Furthermore, digestate can be produced anywhere via anaerobic digestion and is cheap compared to other fertilizers (Owamah et al., 2014). 
Pivato A., Vanin S., Raga R., Lavagnolo M.C., Barausse A., Rieple A., Laurent A., Cossu R. 2016. Use of digestate from a decentralized on-farm biogas plant as fertilizer in soils: An ecotoxicological study for future indicators in risk and life cycle assessment. Waste Management 49, 378-389. http://dx.doi.org/10.1016/j.wasman.2015.12.009.

However, studies have claimed that digestate can still contain an organic fraction not yet completely biodegraded, as well as complex organic elements, salts or pathogenic bacteria that can affect the soil biota (Teglia et al., 2010).

Digestate is not subject to the REACH regulation and only few ecotoxicological studies have been performed to evaluate the ecological impact of digestate application on soil. Digestate information is particularly sparse with regards to their inclusion of organic pollutants and other compounds because its specific composition and characteristics change considerably depending on the type of the feedstock. The lack of data available on the effect of digestate as a whole on terrestrial compartment therefore limits its use in standard risk and impact assessment tools such as life cycle assessment (LCA) (EPA, 2006) and ecological risk assessment (ERA) (EPA, 1998).

In LCA, the ecotoxicity exerted by the digestate once applied on soil have been ignored or dismissed until now. The past LCA studies have thus limited their assessment to modelling the fertilising value of the digestate that replace the use of synthetic fertilisers and therefore saves impacts (e.g. climate change, toxic impacts, resource depletion, etc.) (e.g. Boldrin et al., 2011; Rehl et al., 2011).

In ERA, the assessment has mainly been limited to evaluating the concentrations of a limited number of compounds (heavy metals in primis) and their associated ecotoxicity. This ERA application, oriented to specific chemicals contained in the digestate (substance-based approach), have overlooked important considerations related to the exposure to minor pollutants, the effects of the mixture of the compounds, the biovailability issues and the role of soil substrate (CCME, 1997; RIVM, 2001; EC, 2003; Fishwick, 2004; EPA, 2005).

In order to improve the data on the interactions between the contaminants, the soil matrix and the living organisms in it (Pardo et al., 2014), ecotoxicological assays have to be performed.

Kapanen and Itävaara (2001) proposed ecotoxicological tests for compost application, which have been used by Pivato et al. (2013) in former studies, and which are applied on digestate in this study. The tests carried out can be divided into two categories: direct and indirect tests. According to Pandard et al. (2006) the performance of both direct and indirect tests expand the range of effect expression due to differences in species sensitivity and exposure. 
Pivato A., Vanin S., Raga R., Lavagnolo M.C., Barausse A., Rieple A., Laurent A., Cossu R. 2016. Use of digestate from a decentralized on-farm biogas plant as fertilizer in soils: An ecotoxicological study for future indicators in risk and life cycle assessment. Waste Management 49, 378-389. http://dx.doi.org/10.1016/j.wasman.2015.12.009.

Whereas direct tests deal with the solid-phase sample (Kapanen and Itävaara 2001), indirect tests use an extract of the solid sample to identify its ecotoxicological impact (Alvarenga et al., 2007) and the results depend strongly on the solid-to-liquid ratio assumed

Both methods show advantages and disadvantages. According to Leitgib et al. (2007), direct tests give more realistic results, because all kind of interactions between contaminants, soil matrix and the test organisms are included and all site specific effects are integrated. By contrast, the indirect tests do not examine the risk of the contaminants in the whole soil as an environmental element, but predict only the risk of the contaminants on groundwater.

Concordantly, Domene et al. (2008) reported that direct tests should be the most relevant way due to its closeness to real situations and that indirect tests only give information on the instantaneous bioavailability of the pollutants and not on their long-term bioavailability.

By using both, the direct as well as the indirect approach, a wider range of the resulting effects of the pollutants can be achieved, which is why both options are considered in this study.

The present paper therefore aims to bridge those gaps and has the following objectives:

- to apply the "matrix-based” approach, considering the direct ecotoxicological effects of digestate as a whole on soil biota, by means of a battery of ecotoxicological tests, which included direct and indirect examinations (Kupper et al., 2008; Kapanen and Itävaara 2001; Pivato et al., 2014);

- to define experimentally ecotoxicological parameters $\left(\mathrm{LC} / \mathrm{EC}_{50}\right)$ for the comparison with other studies;

- from a LCA perspective: to provide effect factors that could be used for further calculating characterization factors for assessing terrestrial ecotoxicity impacts from digestate as a whole;

- from an ERA perspective: to define a reference concentration of digestate, considered as a whole, that can be considered acceptable for terrestrial ecosystem.

This scope of this work does not include the assessment of potential indirect ecotoxicological and ecological effects of digestate due to its nutrient content, such as the consequences of leaching of nitrogen and phosphorus to the soil, or of gaseous emissions of nitrogen.

\section{MATERIALS AND METHODS}


Pivato A., Vanin S., Raga R., Lavagnolo M.C., Barausse A., Rieple A., Laurent A., Cossu R. 2016. Use of digestate from a decentralized on-farm biogas plant as fertilizer in soils: An ecotoxicological study for future indicators in risk and life cycle assessment. Waste Management 49, 378-389. http://dx.doi.org/10.1016/j.wasman.2015.12.009.

\subsection{The matrix-based approach}

The current risk assessment methodology makes use of the so-called matrix-based approach, which considers the source of the potential pollutants in the media under consideration as a whole and so doing it takes into account the potential interaction of the toxicants (Perrodin et al., 2011; Sarigiannis and Hansen, 2012).

Compared to the so-called substance-based approach, which relies on the physicochemical analysis of pollutants (e.g. heavy metals) and uses values from international ecotoxicological databases, the matrix-based approach is considered more realistic in terms of "real case scenarios”, as it allows integrating the behaviour of pollutants in mixture and within their real matrix. Furthermore, the matrix-based approach takes better into account phenomena that may potentially change the exposure of organisms. This includes for example the exposure to minor pollutants, which have not been identified when formulating the problem, as well as the exposure to pollutants adsorbed on fine particles and colloids or major pollutants that are not bio-available due to the physicochemical conditions of the environment.

Even though the matrix-based approach does not give any information about individual effects of the substances present in the media, it considers the role of the environment and bioavailability. It is the same principle applied in the concept of "whole effluent toxicity" used in the field of risk assessment of the wastewater effluents (Gotvajn and Zagorc-Koncan, 1998; Sarakinos et al., 2000; Zhou et al., 2013).

Nevertheless, it is possible to use the results obtained from the matrix-based approach combined with the substance-based approach in order to improve the evaluation of the digestate impact (Perrodin et al., 2012).

For the matrix-based approach, batteries of ecotoxicological tests based on five organisms belonging to different ecological levels are used in this study: earthworm [Eisenia fetida (Savigny, 1826)], plants (Lepidium sativum Linnaeus) and aquatic organisms [Vibrio fischeri (Beijerinck 1889), Daphnia magna Straus, 1820 and Artemia Leach, 1819 sp.].

\subsection{Sample characterization of the digestate tested}

The digestate sample used for the battery of bioassays originated from a decentralized onfarm biogas plant of the type widely present in the Veneto farmland (North-Eastern Italy), which is fed with a substrate consisting of cow manure (60 t/d) and triticale (35 t/d as whole 
Pivato A., Vanin S., Raga R., Lavagnolo M.C., Barausse A., Rieple A., Laurent A., Cossu R. 2016. Use of digestate from a decentralized on-farm biogas plant as fertilizer in soils: An ecotoxicological study for future indicators in risk and life cycle assessment. Waste Management 49, 378-389. http://dx.doi.org/10.1016/j.wasman.2015.12.009.

plants), a hybrid type of corn of wheat (Triticum sp.) and rye (Secale sp.). In the biogas plant, the substrate runs through the four phases of the digestion process (hydrolysis, fermentation, acetogenesis, methane formation) with a mean retention time of $80 \mathrm{~d}$. The process is performed in two fermentation reactors (volume $=2,553 \mathrm{~m}^{3}$ each; exercise temperature $=38-42$ ${ }^{\circ} \mathrm{C}$ ) and in one post-fermentation reactor built as the former ones. The produced (by-)product digestate is then stored and naturally aerated for at least $180 \mathrm{~d}$ according to Italian Legislative Decree 217/06 (Dlgs 217/06) to conclude the digestion process.

It is worth mentioning that digestate from only animal manure or from waste has a different composition (Tambone et al., 2015; Fuchs et al., 2008; Alburquerque et al., 2012).

For the evaluation of the physical and chemical properties of the solid sample, different methodologies were used for the relevant parameters: humidity, $\mathrm{pH}$, ammonia nitrogen, organic nitrogen, phosphorus and hexavalent chromium were quantified according to IRSACNR Q 64/84. Conductivity and C/N were measured according to (UNI, Italian Organisation for Standarisation 1998) and the organic carbon was quantified according to UNI EN 13137 2002 (UNI EN 13137 2002). For the quantification of potassium, zinc, cadmium, chromium, copper, nickel and lead EPA n. 3050B/96 + 6010C/07 and for mercury EPA n. 7471 A/94 mod. was used. Respiration index $\left(\mathrm{RI}_{4}, \mathrm{RI}_{7}, \mathrm{mgO} / \mathrm{gDM}\right)$ was determined by means of Sapromat apparatus ( $\mathrm{H}+\mathrm{P}$ Labortechnik, Germany), according to pertinent German regulations for $\mathrm{AT}_{4}$ (Anonymous, 2001).

The chemical characterisation was performed on the eluate, which was extracted from the digestate. To obtain the eluate, $10 \mathrm{~g}$ of the digestate sample were mixed with deionized water with a solid-to-liquid-ratio of 1:50 (referring to the dry matter) into a suitable plastic bottle, which was then mechanically shaken for 24 hours and centrifuged for 15 minutes at 4000 rpm. Lower solid-to-liquid-ratio did not permit a formation of a minimum quantity of eluate to use for chemical characterisation and ecotoxicological tests. The sample was then filtered using a qualitative filter paper to get the final eluate. For the following chemical analyses on the eluate the Italian methodology (APAT and IRSA-CNR 2003) was used, consisting of measurements of the following parameters: $\mathrm{pH}$, conductivity, organic carbon, ammonia nitrogen, organic nitrogen, potassium, phosphorus, zinc, cadmium, chromium, copper, mercury, nickel, lead, hexavalent chromium. 
The physical and chemical properties of the digestate and its eluate are reported in Table 1 and 2.

\subsection{Ecotoxicological tests}

The performed tests are summarized and displayed in Table 3 and described in detail in the following paragraphs.

\subsubsection{Digestate dosage}

Ten different concentrations of digestate were defined for the direct ecotoxicological tests: 0 (control), 2.5, 5, 7.5, 10, 15, 20, 40, 70 and $100 \%$ (w/w referring to the dry matter).

For the direct tests, using directly solid-phase sample, the digestate was mixed in defined proportions with an artificial soil made according to specific guidelines:OECD 222/2004 for earthworm bioassays; APAT 20/2003 and APAT 1/2004 for plant bioassays. The artificial soil was used as the control. The dosages were calculated for the different ratios of digestate in soil and are referred to the dry matter of both.

Common digestate dosages used in agriculture are in the range of 30-60 t/ha*y depending on different crops, different types of soil and spread nitrogen limits. To calculate digestate concentrations in the soil, two cases were distinguished (Pivato et al., 2013): as "good practice" and "bad practice" cases. In the first the digestate is mixed to a depth of $20 \mathrm{~cm}$ with a soil having a density of $1.25 \mathrm{~g} / \mathrm{cm}^{3}$. In the "bad practice": the compost is just spread over the soil (mixing depth of $4 \mathrm{~cm})$ and the soil density is lower $\left(1 \mathrm{~g} / \mathrm{cm}^{3}\right)$. Considering the highest dosage (60 ton/ha*y), the digestate percentage in the soil ranges from $2 \%$ (good practice) to $15 \%$ (bad practice).

For the indirect tests, an eluate of the digestate was obtained according to UNI EN 12457-2. Dilutions of it $(\mathrm{v} / \mathrm{v})$ with distilled water in the above mentioned concentrations, and distilled water as the control were used for the tests. 
Pivato A., Vanin S., Raga R., Lavagnolo M.C., Barausse A., Rieple A., Laurent A., Cossu R. 2016. Use of digestate from a decentralized on-farm biogas plant as fertilizer in soils: An ecotoxicological study for future indicators in risk and life cycle assessment. Waste Management 49, 378-389. http://dx.doi.org/10.1016/j.wasman.2015.12.009.

\subsubsection{Direct tests}

In the direct tests, plants (Lepidium sativum) and earthworms (Eisenia fetida) were directly exposed to a mixture of soil and digestate in different concentrations.

Plant Bioassays. Direct (solid-phase) phytotoxicity tests were conducted with garden cress (Lepidium sativum) in three different ways according to the guidelines APAT 20/2003 (APAT 2003), APAT 1/2004 (APAT 2004) published by the Italian Environment Protection and Technical Services Agency (APAT).

In the Pot Bioassay (PB) the growth rate of the roots under standard conditions $\left(20 \pm 2{ }^{\circ} \mathrm{C}\right.$, water holding capacity (WHC) of $70 \%$, light (20,000 lux) and dark cycles (0 lux) for 16 hours and 8 hours respectively) and for ten different concentrations was examined. For this, plastic pots $(\varnothing=9 \mathrm{~cm}$; $\mathrm{h}=11 \mathrm{~cm}$ ) were filled for three replicates with $500 \mathrm{~g} \pm 5 \mathrm{~g}$ of a calculated amount of artificial soil (sphagnum peat and sand in the ratio 1:1 (v/v)) and digestate, to get ten different concentrations. Ten seeds were put in each pot and covered with a fine layer of sand. Over the five days growth period, the WHC was adjusted daily. The Germination Index (GI) was calculated by multiplying the mean seed germination with the mean root length. The result was then expressed in the percentage with respect to the GI of the control.

The Plant Growth Bioassay was conducted based on APAT 1/2004 with aforementioned conditions and the same pots, in which a $1 \mathrm{~cm}$ layer of expanded clay was filled to improve water drainage. Then $500 \mathrm{~g} \pm 5 \mathrm{~g}$ of the artificial soil (sphagnum peat and sand in the ratio 1:1 $(\mathrm{v} / \mathrm{v}))$ and the digestate were added in different concentrations using three replicates. Twentyfive seeds of garden cress (Lepidium sativum) were put on the media and covered with a fine layer of sand. After the 14 days growth period, the plants were cut, weighed and dried for 24 $\mathrm{h}$ at $70^{\circ} \mathrm{C}$. The Relative Growth (RG) was calculated by dividing the mean dry weight and the mean dry weight of the control and was then expressed in the percentage with respect to the GR of the control.

For the Seed Germination Bioassay (SGB), which was conducted according to the guidelines APAT 20/2003 (APAT 2003), APAT 1/2004 (APAT 2004), Petri dishes (Ø = $9 \mathrm{~cm}$ ) were prepared. $10 \mathrm{~g}$ (referred to the dry matter) of a mixture of quartz sand and digestate in different concentrations were put into the Petri dishes, a calculated amount of deionized water 
Pivato A., Vanin S., Raga R., Lavagnolo M.C., Barausse A., Rieple A., Laurent A., Cossu R. 2016. Use of digestate from a decentralized on-farm biogas plant as fertilizer in soils: An ecotoxicological study for future indicators in risk and life cycle assessment. Waste Management 49, 378-389. http://dx.doi.org/10.1016/j.wasman.2015.12.009.

was added to obtain a WHC of $100 \%$ plus 5 extra milliliters and then a filter paper was placed on top of the media. Ten seeds of garden cress (Lepidium sativum) were put on the filter paper and then the Petri dishes were closed with parafilm. After the incubation time of $72 \mathrm{~h}$ without any light supply at $25 \pm 2{ }^{\circ} \mathrm{C}$, each emerged seedling of the four replicates was washed and the root length was measured. The GI was calculated by multiplying the mean seed germination with the mean root length. The result was then expressed in the percentage with respect to the GI of the control.

Earthworm Bioassays. Direct (solid-phase) toxicity tests were conducted with earthworms (Eisenia fetida) as an acute test according to Pivato et al. ( 2013) and as a chronic test according to the OECD guideline 222/2004 (OECD/OCDE 2004a).

The Earthworm Acute Bioassay (Pivato et al., 2013 and 2014 ) is based on the tendency of the earthworms to bury themselves within 15 minutes in the artificial soil - digestate mixture and was performed right before the chronic bioassay. The behavior of the earthworms is categorized in five classes to describe the observed effects (Table 4). A soil - digestate mixture within classes 1 and 2 and the response "ON" is considered good quality, whereas the classes 3, 4 and 5 stand for the response "OFF”, which stands for bad quality of the mixture.

The Earthworm Chronic Bioassay (ECB) was conducted according to the OECD guideline 222/2004 (OECD/OCDE 2004a) directly after the acute test. Groups of ten adult earthworms with an individual weight of 300 to $600 \mathrm{mg}$, were washed and weighed and then put into the provided plastic containers. These containers were filled with $500 \pm 5 \mathrm{~g}$ (dry matter) of artificial soil prepared according to the OECD guideline 222/2004 (OECD/OCDE 2004a) before and then WHC was adjusted to $40 \%$. The WHC was maintained at $40 \%$ during the whole test period. In order to feed earthworms $5 \mathrm{~g}$ of cow manure were added at the beginning of the test and then weekly . The test was carried out with two replicates and in a thermostatic room with controlled conditions $\left(20 \pm 2{ }^{\circ} \mathrm{C}\right.$, light-dark cycles L (400-800 lux):D (0 lux) 16:8) for 56 days in total.

The ECB can be split into three different approaches. For the first approach (ECB_a) the Survivors (Su) were counted and removed from the containers after 28 days to calculate the mortality rate (\% survival $=100$ - \% mortality). Furthermore, the survivors of the different concentrations in each pot were weighed to calculate the Growth $(\mathrm{Gr})$ of the survivor, i.e. the 
Pivato A., Vanin S., Raga R., Lavagnolo M.C., Barausse A., Rieple A., Laurent A., Cossu R. 2016. Use of digestate from a decentralized on-farm biogas plant as fertilizer in soils: An ecotoxicological study for future indicators in risk and life cycle assessment. Waste Management 49, 378-389. http://dx.doi.org/10.1016/j.wasman.2015.12.009.

increase or decrease of the global earthworm weight per sample, which leads to the second approach (ECB_b).

For the last approach (ECB_c), another 5 g of dry cow manure was added to the containers and for another 28 days they were kept under above-mentioned conditions in the thermostatic room. After four weeks the number of juveniles (Re) hatched was examined.

\subsubsection{Indirect tests}

The “indirect exposure tests” were performed using an eluate (solid-to-liquid ratio 1:50 (v/v)) obtained from the solid digestate sample, by following for the lab operations the guideline UNI EN 12457-2 (UNI EN 12457-2 2004). The indirect tests were performed with garden cress (Lepidium sativum), aquatic organisms (D. magna, Artemia sp.) and luminescent bacteria (Vibrio fischeri).

Plant Bioassays. The indirect Plant Growth Bioassay includes the Seed Germination Eluate Bioassay (SGB_E), which was performed according to UNI 10780-1998 (UNI Ente Nazionale Italiano di Unificazione 1998) and APAT 20/2003 (APAT 2003). $5 \mathrm{ml}$ of the eluate or a dilution of it with distilled water (control) were pipetted in the Petri dishes ( $\varnothing=9 \mathrm{~cm}$ ), a filter paper was added and ten seeds of garden cress were added. The four replicates, with ten different concentrations each, were closed with parafilm and set up in the thermostatic room under controlled conditions (no light supply, $25 \pm 2{ }^{\circ} \mathrm{C}$ ) for $72 \mathrm{~h}$. After the incubation period the root length of each emerged seedling was measured and the GI was calculated.

Aquatic Organisms Bioassay. The indirect test with D. magna (AOB_a) was conducted according to the guideline OECD/OCDE 202/2004 (OECD/OCDE 2004b). Young daphnids aged less than 24 hours were exposed to the eluate or dilutions of it at $20 \pm 2{ }^{\circ} \mathrm{C}$ and immobilization was recorded at 48 hours and compared with control values to calculate the Mobility (Mo).

The indirect test with the brine shrimp Artemia sp. was performed based on the guideline 29/2003 (APAT and IRSA-CNR 2003) published by APAT where Artemia sp. were exposed to the eluate and its dilutions at $20 \pm 1{ }^{\circ} \mathrm{C}$ for 48 hours and their immobility was recorded and compared with control values to calculate the Mobility (Mo).

The Luminescent Bacteria Bioassay was performed with Vibrio fischeri and is based on UNI EN ISO 11348-3:2009. This test was performed with a control (2\% $\mathrm{NaCl}$ solution) and 
several eluate dilutions (two replicates for each treatment). The luminescent bacteria after hydration were placed into a tube containing $10 \mathrm{ml}$ of solution. The light emitted by the bacterial suspension was measured for the purpose of obtaining the initial light. Light reading was performed 5, 15 and 30 min after adding the sample to the bacterial suspension, and the emission end-point (LE) was calculated.

\subsection{Statistical analysis of the performed tests}

For the statistical analysis of the performed tests, two different programs were used. The program EPA Probit analysis v. 1.5allows inserting the data achieved during the experiments to compute the $\mathrm{LC}_{50}$. The $\mathrm{LC}_{50}$ values were calculated with the Probit method in the case of two or more partial mortalities as proposed by U.S. Environmental Protection Agency (EPA,2002).

The Linear Interpolation Methodwas used to determine a point estimate $\left(\mathrm{EC}_{50}\right)$ of the concentration, which is also known as inhibition concentrations (IC) (Norberg-King 1993), that causes a certain reduction (50 \%) referring to the endpoints examined.

\subsection{Determination of HC50 values}

The HC50 value is the hazardous concentration of a chemical at which $50 \%$ of the species are exposed to a concentration above their EC50, and can be used in the development of effect factors for life cycle impact assessment methods addressing ecotoxicity-related impacts -see also Section 4.1 (Larsen and Hauschild, 2007a, 2007b; Henderson et al., 2011).

The HC50 value is defined as the geometric mean of EC50 values and can be derived from either acute or chronic data (Larsen and Hauschild, 2007a, 2007b). In the presence of acute data, an acute-to-chronic ratio (ACR) of 2 is used to extrapolate to chronic EC50 (Henderson et al., 2011). 


\section{$3 \quad$ Results and Discussion}

\subsection{Plant Bioassays}

Figure 1 shows the experimental data of the direct and indirect Plant Bioassays. These include the Pot Bioassay (PB), the Seed Germination Bioassay (SGB) and the Seed Germination Eluate Essay (SGB_E) with germination (expressed by the Germination Index (IG)) as the endpoint, and the Plant Growth Bioassay (PGB) with the Relative Growth (GR) as its endpoint, respectively.

From the results in Figure 1 it can be seen that all graphs show an hormesis trend for the direct tests that indicates favorable biological responses to low exposures to digestates. The trend of the results is an increase of the relative growth and the germination index between $2.5 \%$ and $15 \%$. This means that low digestate doses have a positive effect on the relative growth as well as on the IG of cress plants, whereas high doses have a negative, inhibitory effect. The $\mathrm{LC}_{50}$ for the PB and the SGB were 49.78 and 37.44 respectively (see Table 5 commented in paragraph 3.4). For the PGB no $\mathrm{LC}_{50}$ value could be examined with the results achieved, because the relative growth does not go below $50 \%$. It needs to be said that the control plants of the PGB grew comparatively bad without exception. This leads to a displacement of the curve, which is why even for the high percentages the value for the relative growth is above or close to $100 \%$. The relation to a value of $100 \%$ relative growth might be biased due to the growth of the control, but the hormesis trend in the curve is still apparent.

The reduced growth in the control might be explained with the fact that the artificial soil (1:1 $(\mathrm{v} / \mathrm{v})$ or 12:1 (w/w) sand: sphagnum peat) used for the test itself, did not have enough nutrients. The artificial soil of the PB, for which any reduced growth could not be detected, had a sand-sphagnum peat ratio of 1:1 (w/w). It means that a higher organic fraction was available in the control of the PB compared to the control of the PGB.

Although the tendency of the results of the indirect test (SGB_E) is not as distinctive as those from the direct test, it confirms by trend the results gained through the direct tests. Due to the fact that the eluate was diluted with distilled water for the SGB_E, potential harmful pollutants might have been reduced and their availability diminished. No $\mathrm{LC}_{50}$ is presented for 
the SGB_E, as it was not possible to calculate it; the obtained data were always associated with IG over $50 \%$.

The results of the SGB_E support, therefore, the statement of Leitgib et al. ( 2007): indirect tests do not examine the risk of the contaminants in the soil as a whole.

It is supposed that the salinity of the digestate is the main reason for the inhibition of growth and germination. It is reported by Boluda et al. ( 2011) that salinity levels higher than 2.0 $2.6 \mathrm{mS} / \mathrm{cm}$ can reduce plant growth. Salinity is also assumed to inhibit the number of germinated seeds and to delay the germination process, the leaf development and the root growth (Fernández-Torquemada and Sánchez-Lizaso, 2013).

From literature (ABC, 2015) the electrical conductivity of digestate, that represents the salt concentrations, ranged from 1.0 to $10.0 \mathrm{mS} / \mathrm{cm}$ depending on the typology of substrates and on the treatment options.

In the present research it varied within soil mixture from the maximum value of $3.1 \mathrm{mS} / \mathrm{cm}$ (100\% digestate) to the minimal value of 0.2 and $0.05 \mathrm{mS} / \mathrm{cm}$ respectively for the control (100\% artificial soil) made by sand and peat and the one made by sand only.

In addition, the level of biological stability of the digestate, expressed with the respiration index $\left(\mathrm{RI}_{4}\right.$ and $\left.\mathrm{RI}_{7}\right)$, might be one of the decisive factors for growth and germination inhibition. Moreover, a low stability level might reduce the availability of oxygen in the digestate and show a higher presence of phytotoxic compounds (California Compost Quality Council, 2001).

Compared to a previous study on compost samples from aerobic digestion of segregated organic waste and green waste ( Pivato et al., 2014), the digestate is found less toxic; based on the discussion above, this can be due to the higher values of respiration index $\left(\mathrm{RI}_{4}\right.$ and $\left.\mathrm{RI}_{7}\right)$ and the salinity measured in the compost samples.

Despite the difference in the origin and in the treatment, the two products (digestate and compost) have been compared because they have generally the same application (biofertilizers) in agriculture.

\subsection{Earthworm Bioassay}

The results of the Earthworm Chronic Bioassay (ECB) with the Survival (Su), Relative Growth (Gr) and Reproduction (Re) as its endpoints, are reported in Figure 2. 
It can be seen that there is a hormesis trend regarding the Relative Growth (Gr) and the Reproduction (Re). This demonstrates a beneficial effect for the $\mathrm{Gr}$ and $\mathrm{Re}$ at lower concentrations, whereas at higher concentrations the digestate has a toxic effect on Eisenia fetida.

The decrease in body weight (indirect measure of the growth endpoint) observed for the control and concentrations up to $10 \%$ might be explainable with the lower availability of food resources, as the organic matter content was less than in higher concentrations, like it has already been suggested by Pivato et al. (2013, 2014). The conclusion could be drawn that the amount of dried manure added to the pots was not sufficient.

The high mortality for concentrations higher than $40 \%$ could be explained by the salinity. As reported by Hund-Rinke (2008), the conductivity of $2.04 \mathrm{mS} / \mathrm{cm}$ is lethal for Eisenia fetida. Given the value of $3.1 \mathrm{mS} / \mathrm{cm}$ measured in the digestate, the above reference value is exceeded at higher concentrations.

The results of the Acute Earthworm Bioassay (EAB) in Table 6 confirm the toxic effect of the digestate at higher concentrations as shown above. The earthworms' tendency to bury themselves in the soil-digestate mixture within 15 minutes is high at concentrations from $0 \%$ to $15 \%$ (response: ON, Class: 1 and 2, cf. Table 4) and lower for higher concentrations.

\subsection{Aquatic Organisms and Luminescent Bacteria Bioassays}

The results of the test AOB with the mobility as the endpoint are demonstrated in Figure 3.

For the ASB and LBB no inhibitory effect was observed for 0, 2.5, 5, 7.5, 10, 20, 40 and 70\% concentrations. While for $100 \%$ concentration an inhibition of the mobility with $6.7 \%$ (ASB) and of the light emission with $36 \%$ was obtained.

The $\mathrm{EC}_{50} / \mathrm{LC}_{50}$ toxicity values could be examined only for the AOB (see Table 5 commented in paragraph 3.4). The main reason for the fact that $D$. magna shows a higher sensibility than the halophile Artemia sp. (ASB) (Gajardo and Beardmore 2012) or the marine bacteria Vibrio fischeri (Hernando et al., 2007) is probably due to their minor salinity tolerance. Schuytema et al. (1997) tested the toxicology salinity tolerance of $D$. magna and got a mean value of the $\mathrm{LC}_{50}$ of $10.0 \mathrm{mS} / \mathrm{m}$, which is less than the value measured in the eluate. 
Pivato A., Vanin S., Raga R., Lavagnolo M.C., Barausse A., Rieple A., Laurent A., Cossu R. 2016. Use of digestate from a decentralized on-farm biogas plant as fertilizer in soils: An ecotoxicological study for future indicators in risk and life cycle assessment. Waste Management 49, 378-389. http://dx.doi.org/10.1016/j.wasman.2015.12.009.

\subsection{LC/EC50 values and HC50 derivations}

The ecotoxicological parameters ( $\mathrm{LC}_{50}$ or $\mathrm{EC}_{50}$ values) are reported in Table 5 and they are strongly correlated to the lab test operative conditions; in particular the soil media for the direct tests and the solid-to-liquid ratio for the indirect tests. An accurate application of these parameters in modelling should report these information as a limit of the up-scaling process i.e. the use of data from lab scale to ecosystem investigation.

These values can furthermore be used within the Species Sensitivity Distribution (SSD) approach (Pivato et al., 2014) to determine the $\mathrm{HC}_{50}$ value (see Section 2.5).

For the aquatic compartment, only an $\mathrm{EC}_{50}$ value of $13.6 \%(\mathrm{v} / \mathrm{v})$ for $D$. magna could be estimated. Uncertainties were therefore deemed too important to define an HC50 value from it. In contrast, for terrestrial organisms, two chronic $\mathrm{HC}_{50}$ values could be calculated based on the LC50 and EC50 data from either the acute tests or the chronic tests (see Section 2.5; Larsen and Hauschild, 2007a, 2007b).. In the calculation of the HC50 values, the mean density for soil and digestate, necessary to convert the unit of $\mathrm{LC}_{50} / \mathrm{EC}_{50}$ provided in Table 5 into " $\mathrm{kg} / \mathrm{m}^{3}$ ”, were assumed equal to $1.25 \mathrm{~kg} / \mathrm{dm}^{3}$ and $0.8 \mathrm{~kg} / \mathrm{dm}^{3}$, respectively..

The acute data relate to the two tests conducted on plants, and an acute HC50 defined as the geometric mean of the two EC50 values was thus estimated to $433.5 \mathrm{~kg} / \mathrm{m}^{3}$-soil. Assuming an acute-to-chronic ratio (ACR) of 2 (see Section 2.5), a chronic HC50 value of $216.7 \mathrm{~kg} / \mathrm{m}^{3}$-soil is thus derived. The chronic data relate to the test on earthworms, and a corresponding chronic HC50 of $427.1 \mathrm{~kg} / \mathrm{m}^{3}$-soil is calculated.

In this study, only two trophic levels (either plant or invertebrate) with one species in each could be considered. This represents a limitation. For Species Sensitivity Distribution (SSD) determination the U.S. Environmental Protection Agency ( EPA, 2010) recommends to use data points from at least five species, while Wheeler et al. (2002) suggest to use at least ten data points. In the USEtox model, used in life cycle impact assessment (see Section 4.1), at least three different $\mathrm{EC}_{50}$ values (species) from at least three different trophic levels are recommended as minimum; failing to meet this criteria render the derived HC50 flagged as “interim” (Rosenbaum et al., 2008; Henderson et al., 2011). The use of plants and earthworms, performed in this work, depend on the availability of organisms that can be used for ecotoxicological tests and on the specific substratum (soil) to be tested. Nowadays the 
regulations in countries such as Italy require tests mainly for aquatic organisms in ecotoxicological analysis. Despite their historical and fundamental importance in ecotoxicology, these organisms do not provide useful information when applied to the terrestrial environment because of their biology and the way in which they are in contact with the substance to be tested. In contrast, terrestrial plants and earthworms evolved in order to take nutrients from the soil. Their anatomy and physiology are specific for this environment and consequently sensitive to soil perturbation.

\section{$4 \quad$ Modelling Applications}

The derived ecotoxicological data can help improve the assessment of the ecological impacts and risks from applying digestate as fertilizer on agricultural soil, e.g. via decision-making tools such as LCA and ERA. It is important to note that at the moment such applications are however limited to digestate from farm biogas plants of the same type as the one described synthetically in paragraph 2.2, that use animal manure and energy crops as substrate .

\subsection{Use in life cycle impact assessment method development}

The data generated in the study can serve as inputs to life cycle impact assessment (LCIA) modelling for toxicity-related impact categories. In LCA studies, the LCIA phase primarily consists in translating inventories of pollutant emissions and resource consumptions into impact indicator results representing different environmental problems (e.g. climate change, water depletion, photochemical ozone formation) by use of substance-specific characterization factors (CF). Different characterization models exist to derive CFs for toxicity-related impacts, each relying on different assumptions for modelling the cause-effect chain (e.g. USES-LCA, Huijbregts et al., 2000; CalTOX, Hertwich et al., 2001, McKone et al., 2001; IMPACT 2002, Jolliet et al., 2003; EDIP, Hauschild and Wenzel, 1998). Equation (1) describes the framework for calculating characterization factors for impacts on ecosystems.

$C F=F F \times X F \times E F$

Where: 
- $\mathrm{CF}$ is the characterization factor of the substance considered (here, the digestate is taken as a "whole”), representing the impacts on ecosystems per mass unit of substance emitted.

- FF is fate factor, modelling the fate and transport of the substance (digestate) in the environment after emission.

- $\mathrm{XF}$ is the exposure factor, accounting for the fraction of the substance that is biologically available to the exposed organisms

- $\quad$ EF is the effect factor, reflecting the effects in the exposed organisms.

Using the ecotoxicological data from this study, an EF for digestate can be calculated for the terrestrial ecotoxicity impact category. As an example, the USEtox model is considered here to derive corresponding EF (Hauschild et al., 2008, Rosenbaum et al., 2008). USEtox is a consensus model resulting from the review of the most relevant toxic impact characterisation models commonly used in LCA, and is currently advocated for use by the European Commission in its recommended best practice for LCIA (EC, 2011; Hauschild et al., 2013). The USEtox CFs for ecotoxicity impacts express the potentially affected fraction (PAF) of species integrated over time and soil volume per unit mass of a substance emitted, and are thus expressed in PAF. $\mathrm{m}^{3} . \mathrm{d} / \mathrm{kg}$-emitted or $\mathrm{m}^{3} . \mathrm{d} / \mathrm{kg}$-emitted, the PAF unit being dimensionless (Rosenbaum et al., 2008). The average toxicity, the $\mathrm{HC}_{50}$, is considered in the calculation of the effect factor ( $\mathrm{EF}=0.5 / \mathrm{HC}_{50}$ ), which is expressed in $\mathrm{m}^{3} / \mathrm{kg}$-in-soil (or PAF. $\mathrm{m}^{3} / \mathrm{kg}$-in-soil). Here, values of $\mathrm{EF}_{\text {terrestrial }}=2.31 \mathrm{E}-3 \mathrm{~m}^{3} / \mathrm{kg}$-in-soil and $\mathrm{EF}_{\text {terrestrial }}=1.17 \mathrm{E}-3 \mathrm{~m}^{3} / \mathrm{kg}$-in-soil were derived for terrestrial ecotoxicity using acute data (plant) and chronic data (earthworm), respectively (see Section 3.4). It is important to note that both effect factors should be flagged as "interim" according to the USEtox terminology, and thus requires future improvements. The representation of at least three different trophic levels is indeed recommended to cover a sufficient variability in the biological responses (see also Section 3.4; Rosenbaum et al., 2008; Henderson et al., 2011). Only one trophic level could be assured in each of the two $\mathrm{EF}_{\text {terrestrial }}$ (see Table 5 and Section 3.4). Future studies therefore need to complement the ecotoxicological data provided in this study to allow deriving more robust EF. Until such data are made available, the consideration of the derived interim EFs is advocated. In particular, the EF of $1.17 \mathrm{E}-3 \mathrm{~m}^{3} / \mathrm{kg}$-in-soil derived from the chronic test made on earthworm should be 
prioritised as deemed associated with less uncertainty (i.e. no use of acute-to-chronic extrapolation factor).

The recommended EF needs to be coupled to fate and exposure factors to obtain characterisation factors for digestate as a whole. Similarly to the case of addressing of whole effluent toxicity (Zhou et al., 2013), the use of such characterisation factors is expected to provide a more holistic representation of the impacts from digestate, which is poorly characterised and contains complex mixtures of chemicals, with respect to an approach based on the combined application of characterisation factors for each reported chemical substance composing the digestate.

These CFs will allow including the potential toxic impacts of digestates in LCA studies addressing their application to agricultural soil. One of the strengths of LCA lies in its ability to cover all environmental problems and hence reduce the risk of burden-shifting, e.g. reducing a number of environmental impacts while overlooking the increase of others (Hauschild, 2005). The inclusion of the toxicity exerted by digestates in LCA thus will minimise the risk that such burden-shifting occurs in future studies. It may also unravel relevant environmental problems in the use of digestate as soil amendment that would require addressing from policy-makers.

\subsection{Use in the context of ecological risk assessment (ERA)}

The EU Technical Guidance Document on risk assessment (EC 2003) defines the PNEC as the concentration below which unacceptable effects on organisms will most likely not occur. The ratio between the Predicted Environmental Concentration (PEC) and the PNEC can then be used as an indication of the ecological risk on soil organisms.

The PNEC $_{\text {soll }}$ for the terrestrial compartment can be determined applying the assessment factor method represented by equation (2):

$$
\text { PNEC }_{\text {SOIL }}=\frac{\text { Ecotoxicological Parameter }\left(\mathrm{EC}_{50} ; \mathrm{HC}_{50} ; . .\right)}{A F}
$$

The size of the Assessment Factor (AF; dimensionless) reflects the uncertainity in extrapolating from laboratory toxicity test data, often on single- species, to multi-species ecosystems and the number of trophic levels represented in the data set (see Table 7). Here, an AF of 1000 was selected (see Table 7; EC, 2003). The chronic EC50 value of $427 \mathrm{~g} / \mathrm{dm}^{3}$ 
Pivato A., Vanin S., Raga R., Lavagnolo M.C., Barausse A., Rieple A., Laurent A., Cossu R. 2016. Use of digestate from a decentralized on-farm biogas plant as fertilizer in soils: An ecotoxicological study for future indicators in risk and life cycle assessment. Waste Management 49, 378-389. http://dx.doi.org/10.1016/j.wasman.2015.12.009.

derived from the test on earthworms was considered. A resulting PNECsoil was thus estimated to be equal to 341.7 mg-digestate/kg-soil for soil organisms. In the case of field application, this value is very low but it can be due to the AF assumed (conservative assumption), for this reason further studies are required to improve the estimation.

\section{$5 \quad$ Conclusions and recommendations}

In this study, the utilisation of digestate as biofertiliser in agriculture was assessed by a battery of ecotoxicological tests including direct tests (plant biossays and earthworm biossays) and direct tests (aquatic organism bioassays and luminescent bacteria bioassays)

Direct tests occurred to be more sensitive than indirect tests at least for the solid-to-liquidratio used to obtain the eluates for the indirect tests . The earthworm bioassays did not show serious negative effects for concentrations up to $15 \%$ and the plant bioassays showed no negative effect, but rather a positive one for concentrations lower than $20 \%$, which encourages the use of digestate as a biofertiliser in agriculture provided that correct doses are used. Indirect tests with the aquatic organisms and luminescent bacteria showed an $\mathrm{LC}_{50}$ value of $13.61 \%(\mathrm{v} / \mathrm{v})$ for D. magna and no toxicity for Artemia sp. and Vibrio fischeri.

LCA and ERA appear as potentially useful tools to accommodate these results and combine the matrix-based approach, which allows a sample-specific evaluation as a whole, with the substance-based approach. The former approach allows a more comprehensive assessment, integrating the effect of pollutants in mixture and within their real matrix and can be used efficiently in the cases in which the aim is only to manage the effects of digestate. Instead, in situations, where the investigation of the causes of the digestate effects is needed, the combination of the assessment with a substance-based approach can thus be done. This leads to the possibility of simulating a wider range of situations and allows a more holistic evaluation of the risks and impacts of digestate on terrestrial ecosystems, as opposed to the limitations in the stand-alone use of substance-specific characterization.

Several improvements of the present study are desirable in order to increase the reliability of the derived ecotoxicological parameters for digestates, such as: 
- To implement quality assurance (QA) and quality of product (QC) schemes in which ecotoxicological tests are included.

- To increase the data set of the ecotoxicological data considering factors such as: different test methodologies (number of replicates, different standard solutions), range of possible digesters, feedstock mixtures (from only animal manure or from other wastes), digestate treatment options, presence of specific organic pollutants and pathogens in digestate, intra-annual variability in digestate characteristics. To achieve this goal, more digestate samples should be analyzed. Indeed, this study only investigates the effect of digestate coming from a specific decentralized on-farm biogas plant, a fact limiting the extrapolation of results to other contexts.

- To integrate the battery of ecotoxicological tests used in the current project with new ones such as the Biolog ECOplate tests (Gryta et al., 2014).

\section{Acknowledgements}

This study has been supported by Andrea Borsato, who provided the digestate sample. We thank Dr.ssa Annalisa Sandon, head of the Voltabarozzo Laboratory where this tests were performed.

\section{References}

American Biogas Council (ABC). 2015. Digestate standard, certification \& Testing protocol Program. Outline for development \& use at ABC's digestate standard (draft). In Proceedings of workshop, October 19, 2015, Danvers, Massachuttes.

Alburquerque, J.A., de la Fuente, C., Ferrer-Costa, A., Carrasco, L., Cegarra, J., Abadb, M., Bernal, M.P., 2012. Assessment of the fertiliser potential of digestates from farm and agroindustrial residues. Biomass and Bioenergy, 40, pp.181-189.

Alvarenga, P., Palma, P., Gonçalves, P., Fernandes, R.M., Cunha-Queda, C., Duarte, E., Vallini, G., 2007. Evaluation of chemical and ecotoxicological characteristics of biodegradable organic residues for application to agricultural land. Environment International, 33, pp.505-513.

Anonymous, 2001. Ordinance on Environmentally Compatible Storage of Waste from Human Settlements and on Biological Waste Treatment Facilities, Berlin, Germany (20.02.01.). 
Pivato A., Vanin S., Raga R., Lavagnolo M.C., Barausse A., Rieple A., Laurent A., Cossu R. 2016. Use of digestate from a decentralized on-farm biogas plant as fertilizer in soils: An ecotoxicological study for future indicators in risk and life cycle assessment. Waste Management 49, 378-389. http://dx.doi.org/10.1016/j.wasman.2015.12.009.

APAT (Italian Environmental Agency) and IRSA-CNR (Italian Water Research Institute), 2003. Metodi analitici per le acque.

APAT (Italian Environmental Agency), 2003. Metodi microbiologici di analisi del compost.

APAT (Italian Environmental Agency), 2004. Guida Tecnica Su Metodi Di Analisi Per Il Suolo E I Siti Contaminati.

Boldrin, A., Neidel, L., Damgaard, A., Bhander, G., Møller, J., Christensen, T., 2011. Modelling of environmental impacts from biological treatment of organic municipal waste in EASEWASTE. Waste management, 31(4), pp.619-630.

Boluda, R., Roca-Pérez, L.,Marimón, L., 2011. Soil plate bioassay: An effective method to determine ecotoxicological risks. Chemosphere, 84(1), pp.1-8.

California Compost Quality Council, 2001. Compost Maturity Index.

Canadian Council of Ministers of the Environment (CCME), 1997. Recommended Canadian Soil Quality Guidelines. Documents, c/o Manitoba Statutory Publications, Manitoba, Canada.

Dlgs 217/06 (Italian Legislative Decree 217/06) , Gazzetta ufficiale, n.141 del 20 giugno 2006, Available at: http://www.arpa.veneto.it/temi-ambientali/rifiuti/file-e-allegati/normativa/normativanazionale/2006/dlgs217_06_daGU.pdf.

Domene, X., Alcañiz, J.M.,Andrés, P., 2008. Comparison of solid-phase and eluate assays to gauge the ecotoxicological risk of organic wastes on soil organisms. Environmental Pollution, 151, pp.549558.

EC, 2003. Technical Guidance Document on Risk Assessment in support of Commission Directive 93/67/EEC on Risk Assessment for New notified substances, Commission Regulation (EC) No 1488/94 on Risk Assessment for existing substances, Directive 98/8/EC of the European Parliament and of the Council concerning the placing of biocidal products on the market. Part II. Published by European Commission, Joint Research Centre, Institute for Health and Consumer Protection, Ispra, IT.

EC-JRC, 2011. Recommendations based on existing environmental impact assessment models and factors for life cycle assessment in European context. ILCD Handbookd International Reference Life Cycle Data System, European Union EUR24571EN, ISBN 978-92-79-17451-3.

EPA - United States Environmental Protection Agency, 1994. Method 7471A. Mercury in solid or semisolid waste (manual cold-vapor technique).

EPA - United States Environmental Protection Agency, 1996. Method 3050B. Acid digestion of sediments, sludges, and soils.

EPA - United States Environmental Protection Agency, 1998. Guidelines for Ecological Risk Assessment. EPA/630/R-95/002F. 
Pivato A., Vanin S., Raga R., Lavagnolo M.C., Barausse A., Rieple A., Laurent A., Cossu R. 2016. Use of digestate from a decentralized on-farm biogas plant as fertilizer in soils: An ecotoxicological study for future indicators in risk and life cycle assessment. Waste Management 49, 378-389. http://dx.doi.org/10.1016/j.wasman.2015.12.009.

EPA - United States Environmental Protection Agency, 2002. Methods for Measuring the Acute Toxicity of Effluents and Receiving Waters to Freshwater and Marine Organisms Fifth Edition October 2002. Environmental Protection, p.266.

EPA - United States Environmental Protection Agency, 2005. Guidance for Developing Ecological Soil Screening Levels. OSWER Directive 9285.7-55.

EPA - United States Environmental Protection Agency, 2006. Life Cycle Assessment: principles and practice. EPA/600/R-06/060.

EPA - United States Environmental Protection Agency, 2007. Method 6010C. Inductively coupled plasma-atomic emission spectrometry.

EPA - United States Environmental Protection Agency, 2010. Causal Analysis/Diagnosis Decision Information System (CADDIS). Office of Research and Development, Washington, DC. Available at: http://www.epa.gov/caddis [Accessed February 18, 2015].

EurObserv'ER, 2013. The State of Renewable Energies in Europe, Available at: http://www.eurobserv-er.org/downloads.asp.

Fachverband Biogas e.V., European Biogas Associatio, BiPRO, 2013. Position Paper on Digestate and REACH, Available at: http://www.biogas.org/edcom/webfvb.nsf/id/DE_Ausnahme-fuerGaerprodukte-von-der-REACH-

Verordnung/\$file/2013+11+28+Position+paper+digestate+and+REACH+EN+final.pdf

Fernández-Torquemada, Y., Sánchez-Lizaso, J.L, 2013. Effects of salinity on seed germination and early seedling growth of the Mediterranean seagrass Posidonia oceanica (L.) Delile. Estuarine, Coastal and Shelf Science, 119, pp.64-70.

Fishwick, S., 2004. Soil Screening Values For Use in UK Ecological Risk Assessment.

Fuchs, J.G., Berner, A., Mayer, J., Schleiss, K., Kupper, T., 2008. Effects of compost and digestate on environment and plant production - results of two research projects . ORBIT 2008.

Gajardo, G.M., Beardmore, J. A., 2012. The brine shrimp Artemia: Adapted to critical life conditions. Frontiers in Physiology, pp.1-8.

Gómez, X., Cuetos, M.J., García, A.I., Morán, A., 2005. Evaluation of digestate stability from anaerobic process by thermogravimetric analysis. Thermochimica Acta, 426(1-2), pp.179-184.

Gotvajn, A.Z., Zagorc-Koncan, J., 1998. Whole effluent and single substance approach: a tool for hazardous wastewater management. Water Science Technology 37(8), pp.219-227.

Govasmark, E., Stäb, J., Holen, B., Hoornstra,D., Nesbakk, T., Salkinoja-Salonen, M., 2011. Chemical and microbiological hazards associated with recycling of anaerobic digested residue intended for agricultural use. Waste Management, vol. 31, no. 12, pp.2577-2583. 
Pivato A., Vanin S., Raga R., Lavagnolo M.C., Barausse A., Rieple A., Laurent A., Cossu R. 2016. Use of digestate from a decentralized on-farm biogas plant as fertilizer in soils: An ecotoxicological study for future indicators in risk and life cycle assessment. Waste Management 49, 378-389. http://dx.doi.org/10.1016/j.wasman.2015.12.009.

Gryta, A., Frąc, M., Karolina, O., 2014. The Application of the Biolog EcoPlate Approach in Ecotoxicological Evaluation of Dairy Sewage Sludge. In Appl Biochem Biotechnol. 2014; 174(4): 1434-1443.

Hauschild M, Wenzel H . 1998. Environmental assessment of products, vol 2: scientific background. Kluwer, Hingham, MA, USA, p 565

Hauschild, M., 2010. Modelling life cycle impacts of toxics on humans and ecosystems with the USEtox TM model 1-day course, Available at: http://www.usetox.org/sites/default/files/supporttutorials/calculating_cfs.pdf.

Hauschild, M.Z., 2005. Assessing environmental impacts in a life-cycle perspective. International Environmental Science and Technology 39, pp.81A-88A.

Hauschild, M.Z., Goedkoop, M., Guinée, J., Heijungs, R., Huijbregts, M.A.J., Jolliet, O., Margni, M., De Schryver, A., Humbert, S., Laurent, A., Sala, S., Pant, R., 2013. Identifying best existing practice for characterization modeling in life cycle impact assessment. International Journal of Life-Cycle Assessement 18, 683-697.

Henderson, A.D., Hauschild, M.Z., Van De Meent, D., Huijbregts, M., Larsen, H.F., Margni, M., McKone, T.E., Payet, J. Rosenbaum, R., Jolliet, O., 2011. USEtox fate and ecotoxicity factors for comparative assessment of toxic emissions in life cycle analysis: Sensitivity to key chemical properties. International Journal of Life Cycle Assessment, 16, pp.701-709.

Hernando, M.D., De Vettori, S., Martínez Bueno, M.J., Fernández-Alba, A.R., 2007. Toxicity evaluation with Vibrio fischeri test of organic chemicals used in aquaculture. Chemosphere, 68, pp.724-730.

Hertwich E., Matales S.F., Pease WS, McKone T.E., 2001. Human toxicity potentials for life-cycle assessment and toxics release inventory risk screening. Environmental Toxicology and Chemistry 20(4):928-939

Holm-Nielsen, J.B., Al Seadi, T.,Oleskowicz-Popiel, P., 2009. The future of anaerobic digestion and biogas utilization. Bioresource technology, 100(22), pp.5478-84.

Huijbregts M.A.J., Thissen U, Guinée J.B., Jager T, Kalf D, van de Meent D, Ragas A.M.J., Wegener Sleeswijk A., Reijnders L., 2000. Priority assessment of toxic substances in life cycle assessment. Part I: calculation of toxicity potentials for 181 substances with the nested multi-media fate, exposure and effects model USES-LCA. Chemosphere 41(4):541-573

Hund-Rinke, K., 2008. Benefit of ecotoxicological tests for the characterization of waste. Presentation. cited in Pivato et. al, 2014

Jolliet O., Margni M., Charles R., Humbert S., Payet J., Rebitzer G., Rosenbaum R.K., 2003. IMPACT 2002+: a new life cycle impact assessment methodology. International Journal of Life Cycle Assessment 8(6):324-330 
Pivato A., Vanin S., Raga R., Lavagnolo M.C., Barausse A., Rieple A., Laurent A., Cossu R. 2016. Use of digestate from a decentralized on-farm biogas plant as fertilizer in soils: An ecotoxicological study for future indicators in risk and life cycle assessment. Waste Management 49, 378-389. http://dx.doi.org/10.1016/j.wasman.2015.12.009.

Kapanen, A. Itävaara, M., 2001. Ecotoxicity tests for compost applications. Ecotoxicology and environmental safety, 49, pp.1-16.

Kupper, T., Brändli, R.C., Bucheli, T.D., Stämpfli, C., Zennegg, M., Berger, U., Edder, P., Pohl, M., Niang, F., Iozza, S.; Müller, J., Schaffner, C., Schmid, P., Huber, S., Ortelli, D., Becker-van Slooten, K., Mayer, J., Bachmann, H.J., Stadelmann, F.X., Tarradellas, J, 2008. Organic pollutants in compost and digestate : occurrence, fate and impacts. CODIS 2008 (27-34). ISBN: 978-3-03736-016-3

Larsen HF, Hauschild MZ., 2007a. Evaluation of ecotoxicity effect indicators for use in LCIA. International Journal of Life Cycle Assessment 12(1):24-33.

Larsen HF, Hauschild MZ., 2007b. GM-troph - a low data demand ecotoxicity effect indicator for use in LCIA. International Journal of Life Cycle Assessment. 12(2):79-91.

Leitgib, L., Kálmán, J., Gruiz, K., 2007. Comparison of bioassays by testing whole soil and their water extract from contaminated sites. Chemosphere, 66, pp.428-434.

McKone T., Bennett D., Maddalena R., 2001. CalTOX 4.0 Technical support document, vol 1. LBNL47254, Lawrence Berkeley. National Laboratory, Berkeley, CA

Norberg-King, T., 1993. A linear interpolation method for sublethal toxicity: The inhibition concentration (ICp) Approach. National Effluent Toxicity Assessment Center, Technical Report 0393, Environmental Protection Agency, Environmental Agency, Environmental Research LaboratoryDuluth, Duluth, MN 55804.

OECD/OCDE, 2004a. OECD Guidelines for the Testing of Chemicals. Test No. 222: Earthworm Reproduction Test (Eisenia fetida/ Eisenia andrei).,.

OECD/OCDE, 2004b. OECD Guideline 202/2004 for testing of chemicals. Test No. 202: Daphnia sp., Acute Immobilisation Test.

Ortiz-Gutiérrez, R.A., Giarola, S.,Bezzo, F., 2013. Optimal design of ethanol supply chains considering carbon trading effects and multiple technologies for side-product exploitation. Environmental Technology, 34, pp.2189-2199.

Owamaha, H.I., Dahunsi, S.O., Oranusi, U.S., Alfa, M.I., 2014. Fertilizer and sanitary quality of digestate biofertilizer from the co-digestion of food waste and human excreta. Waste Management, 34, pp. 747-752

Payet J., 2004. Assessing toxic impacts on aquatic ecosystems in life cycle assessment (LCA). Thesis Faculté Environnement Naturel, Architectural Et Construit. DEA, INSA, Lyon, France.

Pandard, P., Devillers, J., Charissou, A.M., Poulsen, V., Jourdain, M.J., Férard, J.F., Grand, C., Bispo, A., 2006. Selecting a battery of bioassays for ecotoxicological characterization of wastes. Science of the Total Environment, 363, pp.114-125.

Pardo, T., Clemente, R., Epelde, L., Garbisu, C., Bernal, M.P., 2014. Evaluation of the phytostabilisation efficiency in a trace elements contaminated soil using soil health indicators. Journal of Hazardous Materials, 268, pp.68-76. 
Pivato A., Vanin S., Raga R., Lavagnolo M.C., Barausse A., Rieple A., Laurent A., Cossu R. 2016. Use of digestate from a decentralized on-farm biogas plant as fertilizer in soils: An ecotoxicological study for future indicators in risk and life cycle assessment. Waste Management 49, 378-389. http://dx.doi.org/10.1016/j.wasman.2015.12.009.

Perrodin, Y., Boillot, C., Angerville, R., Donguy, G., Evens, E., 2011. Ecological risk assessment of urban and industrial systems: A review. Science of the Total Environment, 409(24), pp.5162-5176.

Perrodin, Y., Donguy, G., Bazin, C., Volatier, L., Durrieu, C., Bony, S., Devaux, A., Abdelghafour, M., Moretto, R., 2012. Ecotoxicological risk assessment linked to infilling quarries with treated dredged seaport sediments. Science of the Total Environment, 431, pp.375-384.

Pivato, A., Raga, R., Lavagnolo, M.C., Vanin, A., Barausse, L., Palmeri, L., Cossu, R., 2014. Assessment of compost dosage in farmland through ecotoxicological tests. Journal of Material Cycles and Waste Management. DOI: 10.1007/s10163-014-0333-z

Pivato, A., Raga, R., Vanin, S., Rossi, M., 2013. Assessment of compost quality for its environmentally safe use by means of an ecotoxicological test on a soil organism. Journal of Material Cycles and Waste Management. DOI: 10.1007/s10163-013-0216-8.

Rauch, J., 1998. Teil I: Grundlagen 1 Definition von Mehrproduktanlagen und Flexibilitätsanforderungen.

Rehl, T., Müller, J.. 2011. Life cycle assessment of biogas digestate processing technologies. In Resources, Conservation and Recycling 56 (2011) 92- 104.

RIVM (National Institute of Public Health and the Environment of Netherlands), 2001. Guidance Document on deriving Environmental Risk Limits. RIVM Report 601501012.”

Rosenbaum, R.K., Bachmann, T.M., Gold, L.S., Huijbregts, M., Jolliet, O., Juraske, R., Koehler, A., Larsen, H.F., MacLeod, M., Margni, M., McKone, T.E., Payet, J., Schuhmacher, M., Van De Meent, D., Hauschild, M.Z., 2008. USEtox - The UNEP-SETAC toxicity model: Recommended characterisation factors for human toxicity and freshwater ecotoxicity in life cycle impact assessment. International Journal of Life Cycle Assessment, 13, pp.532-546.

Sarakinos, H. C., Bermingham, N., White, P. A., Rasmussen, J. B., 2000. In Environmental Toxicology and Chemistry, 19(1) pp. 63-71

Sarigiannis, D. , Hansen, U., 2012. Considering the cumulative risk of mixtures of chemicals - a challenge for policy makers. Environmental Health.

Schuytema, G.S., Nebeker, V., Stutzman, T.W., 1997. Environmental Contamination and Toxicology Salinity Tolerance of Daphnia magna and Potential Use for Estuarine Sediment Toxicity Tests, 198, pp.194-198.

Tambone, F., Terruzzi, L. Scaglia, B., Adani, F. 2015 . Composting of the solid fraction of digestate derived from pig slurry: Biological processes and compost properties. Waste Management, 35, 2015, pp.55-61

Teglia, C., Tremier, A.,Martel, J.-L., 2010. Characterization of Solid Digestates: Part 1, Review of Existing Indicators to Assess Solid Digestates Agricultural Use. Waste and Biomass Valorization, 2(1), pp.43-58. 
Pivato A., Vanin S., Raga R., Lavagnolo M.C., Barausse A., Rieple A., Laurent A., Cossu R. 2016. Use of digestate from a decentralized on-farm biogas plant as fertilizer in soils: An ecotoxicological study for future indicators in risk and life cycle assessment. Waste Management 49, 378-389. http://dx.doi.org/10.1016/i.wasman.2015.12.009.

Tercero, E.A.R., Alibardi, L., Cossu, R., Bertucco, A.., 2014. Anaerobic digestion of microalgal residues to enhance the energetic profit of biocrude production. Chemical Engineering Transactions, 37, pp.793-798.

UNI EN 12457-2, 2004. Caratterizzazione dei rifiuti - Lisciviazione - Prova di conformità per la lisciviazione di rifiuti granulari e di fanghi - Parte 2: Prova a singolo stadio, con un rapporto liquido/solido di 10 l/kg, per materiali con particelle di dimensioni minori di 4,

UNI EN 13137, 2002. Charakterisierung von Abfall - Bestimmung des gesamten organischen Kohlenstoffs (TOC) in Abfall, Schlämmen und Sedimenten; Deutsche Fassung

UNI Italian Organisation for Standarisation, 1998. UNI 10780 - 1998. , 44(0), pp.0-9.

Wheeler, J.R., Grist, E.P.M., Leung, K.M.Y, Morritt, D., Crane, M., 2002. Species sensitivity distributions: data and model choice. Marine pollution bulletin, 45, pp.192-202.

Zhou J., Chang V.W.-C., Fane A.G., 2013. An improved life cycle impact assessment (LCIA) approach for assessing aquatic eco-toxic impact of brine disposal from seawater desalination plants. Desalination 308, 233-241. 
Table 1. Physical and chemical properties of the analysed digestate

\begin{tabular}{|c|c|c|c|c|}
\hline Parameter & Units & Value & Limit $^{*}$ & Method \\
\hline Humidity $(\mathrm{H})$ & $\%$ & 72.5 & 50 & IRSA-CNR Q 64/84 vol. 2 n. 2 \\
\hline Dry matter & $\%$ & 27.5 & - & IRSA-CNR Q 64/84 vol. 2 n. 2 \\
\hline $\mathrm{pH}$ & - & 8.2 & $6.0-8.8$ & IRSA-CNR Q 64/85 vol. 3 n. 1 \\
\hline Conductivity & $\mathrm{mS} / \mathrm{cm}$ & 3.1 & - & UNI $10780: 1998$ \\
\hline TOC & $\% \mathrm{dm}$ & 38.4 & $>20$ & UNI EN 13137 \\
\hline Ammonium & $\% \mathrm{dm}$ & 0.94 & 0.2 & IRSA-CNR Q 64/86 vol. 3 n. 7 mod. \\
\hline TKN & $\% \mathrm{dm}$ & 2.9 & - & ISRA-CNR Q 64/85 vol. 3 n. 6 mod. \\
\hline $\mathrm{C} / \mathrm{N}$ ratio & - & 13 & 25 & UNI $10780: 1998$ \\
\hline Potassium & $\mathrm{mgK} / \mathrm{kg}_{\mathrm{dm}}$ & 119 & - & EPA n. 3050B/96 + 6010C/07 \\
\hline Phosphorus & $\mathrm{mgP} / \mathrm{kg}_{\mathrm{dm}}$ & 8433 & - & IRSA-CNR Q 64/85 vol. 3 n. 9 \\
\hline Zinc & $\mathrm{mgZn} / \mathrm{kg}_{\mathrm{dm}}$ & 122 & 500 & EPA n. 3050B/96 + 6010C/07 \\
\hline Cadmium & $\mathrm{mgCd} / \mathrm{kg}_{\mathrm{dm}}$ & $<0.5$ & 1.5 & EPA n. 3050B/96 + 6010C/07 \\
\hline Chromium & $\mathrm{mgCr} / \mathrm{kg}_{\mathrm{dm}}$ & 2.69 & - & EPA n. 3050B/96 + 6010C/07 \\
\hline Copper & $\mathrm{mgCu} / \mathrm{kg}_{\mathrm{dm}}$ & 20.5 & 230 & EPA n. 3050B/96 + 6010C/07 \\
\hline Mercury & $\mathrm{mgHg} / \mathrm{kg}_{\mathrm{dm}}$ & 0.7 & 1.5 & EPA n. 7471 A/94 mod. \\
\hline Nickel & $\mathrm{mgNi} / \mathrm{kg}_{\mathrm{dm}}$ & 2.47 & 100 & EPA n. 3050B/96 + 6010C/07 \\
\hline Lead & $\mathrm{mgPb} / \mathrm{kg}_{\mathrm{dm}}$ & 7.03 & 140 & EPA n. 3050B/96 + 6010C/07 \\
\hline Hexavalent chromium & $\mathrm{mgCr} \mathrm{VI/kg} \mathrm{dm}_{\mathrm{dm}}$ & 2.69 & 0.5 & IRSA-CNR Q 64/86 vol. 3 n. 16 \\
\hline Respiration index $(4)^{(* *)}$ & $\mathrm{mgO}_{2} / \mathrm{kg}_{\mathrm{dm}}$ & 3.7 & - & $*$ \\
\hline Respiration index $(7)^{(* *)}$ & $\mathrm{mgO}_{2} / \mathrm{kg}_{\mathrm{dm}}$ & 5.6 & - & $*$ \\
\hline
\end{tabular}

* Acceptable limits for the quality of fertilizer for agricultural use in accordance with Italian regulation (Annex 2 of the Decreto Legislativo (Italian Legislative Decree) n.75/2010,); no specific limit values are available for digestate, therefore the limits are to be considered just a reference.

** Respiration index (4) for 4 days, respiration index (7) for 7 days 
Pivato A., Vanin S., Raga R., Lavagnolo M.C., Barausse A., Rieple A., Laurent A., Cossu R. 2016. Use of digestate from a decentralized on-farm biogas plant as fertilizer in soils: An ecotoxicological study for future indicators in risk and life cycle assessment. Waste Management 49, 378-389. http://dx.doi.org/10.1016/j.wasman.2015.12.009.

Table 2. Chemical properties of the analyzed digestate eluate (1:50)

\begin{tabular}{|c|c|c|c|}
\hline Parameter & Units & Value & Method \\
\hline $\mathrm{pH}$ & - & 8.23 & IRSA-CNR 29/2003 vol. 1 n. 2060 \\
\hline Conductivity & $\mathrm{mS} / \mathrm{cm}$ & 1.65 & IRSA-CNR 29/2003 vol. 1 n. 2030 \\
\hline TOC & $\mathrm{mgC} / \mathrm{l}$ & 186 & IRSA-CNR 29/2003 vol. 2 n. 5040 \\
\hline Ammonium & $\mathrm{mgNH}_{4}-\mathrm{N} / \mathrm{l}$ & 935 & IRSA-CNR 29/2003 vol. 2 n. 4030 A2, C \\
\hline TKN & mgN/l & 72.2 & IRSA-CNR 29/2003 vol. 2 n. 5030 \\
\hline $\mathrm{C} / \mathrm{N}$ ratio & - & & - \\
\hline Potassium & $\mu g K / l$ & 241 & IRSA-CNR 29/2003 vol. 1 n. 3020 \\
\hline Phosphorus & $\mathrm{mgP} / \mathrm{l}$ & 62.6 & IRSA-CNR 29/2003 vol. 2 n. 4110 A1, A2 \\
\hline Zinc & $\mu \mathrm{gZn} / \mathrm{l}$ & 146 & IRSA-CNR 29/2003 vol. 1 n. 3020 \\
\hline Cadmium & $\mu g C d / l$ & $<10$ & IRSA-CNR 29/2003 vol. 1 n. 3020 \\
\hline Chromium & $\mu \mathrm{gCr} / \mathrm{l}$ & $<10$ & IRSA-CNR 29/2003 vol. 1 n. 3020 \\
\hline Copper & $\mu g C u / l$ & 87.3 & IRSA-CNR 29/2003 vol. 1 n. 3020 \\
\hline Mercury & $\mu g H g / l$ & 28.3 & IRSA-CNR 29/2003 vol. 1 n. 3020 A1 mod. \\
\hline Nickel & $\mu g N i / l$ & $<10$ & IRSA-CNR 29/2003 vol. 1 n. 3020 \\
\hline Lead & $\mu g \mathrm{~Pb} / \mathrm{l}$ & $<10$ & IRSA-CNR 29/2003 vol. 1 n. 3020 \\
\hline $\begin{array}{c}\text { Hexavalent } \\
\text { chromium }\end{array}$ & $\mu \mathrm{gCr} \mathrm{VI} / \mathrm{l}$ & $<10$ & IRSA-CNR 29/2003 vol. 1 n. 3150 C \\
\hline
\end{tabular}




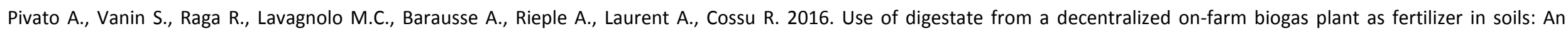
ecotoxicological study for future indicators in risk and life cycle assessment. Waste Management 49, 378-389. http://dx.doi.org/10.1016/i.wasman.2015.12.009.

Table 3. Summary of tests performed

\begin{tabular}{|c|c|c|c|c|c|c|c|c|c|c|c|c|c|}
\hline Test & Organism & $\begin{array}{l}\text { Number per } \\
\text { concentration }\end{array}$ & Replicates & Media & Dose & $\begin{array}{c}\text { Quantity } \\
\text { (dry matter) }\end{array}$ & Duration & $\begin{array}{l}\text { Temperature } \\
\left({ }^{\circ} \mathrm{C}\right)\end{array}$ & L:D & $\begin{array}{c}\mathbf{L} \\
\text { (lux) }\end{array}$ & $\begin{array}{l}\text { WHC } \\
(\%)\end{array}$ & Endpoint & Method \\
\hline \multicolumn{14}{|c|}{ Plant Bioassays } \\
\hline Pot Bioassay (PB) & $\begin{array}{l}\text { Lepidium } \\
\text { sativum }\end{array}$ & 10 & 3 & $\begin{array}{c}\text { soil } \\
\text { (sand/peat) }\end{array}$ & digestate & $500 \mathrm{~g}$ & $5 \mathrm{~d}$ & $20 \pm 2$ & 16:08 & 20000 & 70 & Germination & $\begin{array}{c}\text { APAT 20/2003, APAT } \\
1 / 2004\end{array}$ \\
\hline $\begin{array}{l}\text { Plant Growth Bioassay } \\
\text { (PGB) }\end{array}$ & $\begin{array}{l}\text { Lepidium } \\
\text { sativum }\end{array}$ & 25 & 3 & $\begin{array}{c}\text { soil } \\
\text { (sand/peat) }\end{array}$ & digestate & $500 \mathrm{~g}$ & $5 \mathrm{~d}$ & $20 \pm 2$ & 16:08 & 20000 & 70 & $\begin{array}{l}\text { Relative } \\
\text { Growth (RG) }\end{array}$ & APAT 1/2004 \\
\hline $\begin{array}{l}\text { Seed Germination Bioassay } \\
\text { (SGB) }\end{array}$ & $\begin{array}{l}\text { Lepidium } \\
\text { sativum }\end{array}$ & 10 & 4 & soil (sand) & $\begin{array}{l}\text { eluate } \\
(1: 50)\end{array}$ & $10 \mathrm{~g}$ & $72 \mathrm{~h}$ & $25 \pm 2$ & $00: 24$ & - & 100 & Germination & $\begin{array}{c}\text { APAT 20/2003, APAT } \\
1 / 2004\end{array}$ \\
\hline $\begin{array}{l}\text { Seed Germination Eluate } \\
\text { Bioassay (SGB_E) }\end{array}$ & $\begin{array}{l}\text { Lepidium } \\
\text { sativum }\end{array}$ & 10 & 4 & $\begin{array}{l}\text { solution } \\
\text { (water) }\end{array}$ & $\begin{array}{l}\text { eluate } \\
(1: 50)\end{array}$ & $5 \mathrm{ml}$ & $72 \mathrm{~h}$ & $25 \pm 2$ & $00: 24$ & - & - & Germination & $\begin{array}{l}\text { UNI 10780-1998, } \\
\text { APAT 20/2003 }\end{array}$ \\
\hline \multicolumn{14}{|c|}{ Earthworm Bioassays } \\
\hline $\begin{array}{l}\text { Earthworm Chronic } \\
\text { Bioassay (ECB_a) }\end{array}$ & Eisenia fetida & 10 & 2 & $\begin{array}{c}\text { soil } \\
\text { (OECD } \\
\text { soil) } \\
\end{array}$ & digestate & $500 \mathrm{~g}$ & $28 \mathrm{~d}$ & $20 \pm 2$ & 16:08 & 20000 & 40 & Survivor (Su) & OECD 222/2004 \\
\hline $\begin{array}{l}\text { Earthworm Chronic } \\
\text { Bioassay (ECB_b) }\end{array}$ & Eisenia fetida & 10 & 2 & $\begin{array}{c}\text { soil } \\
\text { (OECD } \\
\text { soil) } \\
\end{array}$ & digestate & $500 \mathrm{~g}$ & $28 \mathrm{~d}$ & $20 \pm 2$ & 16:08 & 20000 & 40 & Growth (Gr) & OECD 222/2004 \\
\hline $\begin{array}{l}\text { Earthworm Chronic } \\
\text { Bioassay (ECB_c) }\end{array}$ & Eisenia fetida & 10 & 2 & $\begin{array}{c}\text { soil } \\
\text { (OECD } \\
\text { soil) } \\
\end{array}$ & digestate & $500 \mathrm{~g}$ & $28 \mathrm{~d}$ & $20 \pm 2$ & 16:08 & 20000 & 40 & $\begin{array}{l}\text { Reproduction } \\
\quad(\mathrm{Re})\end{array}$ & OECD 222/2004 \\
\hline $\begin{array}{c}\text { Earthworm Acute Bioassay } \\
\text { (EAB) }\end{array}$ & Eisenia fetida & 10 & 2 & $\begin{array}{l}\text { soil } \\
\text { (OECD } \\
\text { soil) }\end{array}$ & digestate & $500 \mathrm{~g}$ & $15 \mathrm{~min}$ & $20 \pm 2$ & 16:08 & 20000 & 40 & $\begin{array}{l}\text { Tendency to } \\
\text { digging } \\
\text { (ON/OFF) }\end{array}$ & Pivato et al. 2013 \\
\hline \multicolumn{14}{|c|}{ Aquatic Organisms and Luminescent Bacteria Bioassay } \\
\hline $\begin{array}{l}\text { Aquatic Organism Bioassay } \\
\text { (AOB_a) }\end{array}$ & $\begin{array}{l}\text { Daphnia } \\
\text { magna }\end{array}$ & 5 & 4 & $\begin{array}{l}\text { solution } \\
\text { (water) }\end{array}$ & $\begin{array}{l}\text { eluate } \\
(1: 50)\end{array}$ & $50 \mathrm{ml}$ & $48 \mathrm{~h}$ & $20 \pm 2$ & 16:08 & - & - & Mobility (Mo) & $\begin{array}{l}\text { OECD/OCDE } \\
\text { 202/2004 }\end{array}$ \\
\hline $\begin{array}{c}\text { Aquatic Organism Bioassay } \\
\text { (AOB_b) }\end{array}$ & Artemia sp. & 10 & 3 & $\begin{array}{l}\text { saline } \\
\text { solution }\end{array}$ & $\begin{array}{l}\text { eluate } \\
(1: 50)\end{array}$ & $12 \mathrm{ml}$ & $24 \mathrm{~h}$ & $20 \pm 2$ & 01:23 & $\begin{array}{c}3000- \\
4000\end{array}$ & - & Mobility (Mo) & $\begin{array}{c}\text { APAT CNR IRSA } \\
8060 \text { MAN } 292003\end{array}$ \\
\hline $\begin{array}{l}\text { Luminescent Bacteria } \\
\text { Bioassay (LBB) }\end{array}$ & Vibrio fischeri & - & 2 & $\begin{array}{l}\text { solution (2 } \\
\% \mathrm{NaCL})\end{array}$ & $\begin{array}{l}\text { eluate } \\
(1: 50)\end{array}$ & $10 \mathrm{ml}$ & $15 \min$ & $20 \pm 2$ & - & - & - & $\begin{array}{l}\text { Light emission } \\
\text { (LE) }\end{array}$ & $\begin{array}{l}\text { UNI EN ISO 11348- } \\
\text { 3:2009 }\end{array}$ \\
\hline
\end{tabular}


Pivato A., Vanin S., Raga R., Lavagnolo M.C., Barausse A., Rieple A., Laurent A., Cossu R. 2016. Use of digestate from a decentralized on-farm biogas plant as fertilizer in soils: An ecotoxicological study for future indicators in risk and life cycle assessment. Waste Management 49, 378-389. http://dx.doi.org/10.1016/j.wasman.2015.12.009.

Table 5. $\mathrm{LC}_{50}$ and EC50 values for the performed tests

\begin{tabular}{|c|c|c|c|}
\hline Bioassay & $\mathbf{L C}_{50} / \mathbf{E C}_{50}$ & 95\% Confidence limits & Method \\
\hline \multicolumn{4}{|l|}{ Plant Bioassays } \\
\hline Pot Bioassay & $49.78 \%(\mathrm{w} / \mathrm{w} \mathrm{dm})$ & $40.95-54.63(\mathrm{w} / \mathrm{w} \mathrm{dm})$ & Linear interpolation method \\
\hline Plant Growth Bioassay & -- & -- & \\
\hline Seed Germination Bioassay & $37.44 \%(w / w d m)$ & $14.79-59.15(\mathrm{w} / \mathrm{w} \mathrm{dm})$ & Linear interpolation method \\
\hline Seed Germination Eluate Bioassay & -- & -- & \\
\hline \multicolumn{4}{|l|}{ Earthworm Bioassays } \\
\hline Earthworm Chronic Bioassay $(*)$ & $42.30 \%(w / w d m)$ & $32.62-53.13(\mathrm{w} / \mathrm{w} \mathrm{dm})$ & PROBIT \\
\hline \multicolumn{4}{|c|}{ Aquatic organisms and luminescent bacteria bioassay } \\
\hline Daphnia magna & $13.61 \%(\mathrm{v} / \mathrm{v})$ & & PROBIT \\
\hline Artemia sp. & -- & -- & \\
\hline Vibrio fischeri & -- & -- & \\
\hline
\end{tabular}

$\left(^{*}\right)$ based on survival endpoint 
Pivato A., Vanin S., Raga R., Lavagnolo M.C., Barausse A., Rieple A., Laurent A., Cossu R. 2016. Use of digestate from a decentralized on-farm biogas plant as fertilizer in soils: An ecotoxicological study for future indicators in risk and life cycle assessment. Waste Management 49, 378-389. http://dx.doi.org/10.1016/j.wasman.2015.12.009.

Table 4. Adaption of the earthworm in the soil-compost mixture within 15 minutes used in the Earthworm Acute Bioassay (EAB)

\begin{tabular}{cccclcc}
\hline Class & Name & $\begin{array}{c}\text { Time } \\
(\mathbf{m i n})\end{array}$ & Burial \% & \multicolumn{1}{c}{ Behavior description } & response \\
\hline $\mathbf{1}$ & $\begin{array}{c}\text { Optimum } \\
\text { adaptation }\end{array}$ & $<5$ & 100 & Immediate burial of all earthworms in few minutes & ON \\
\hline $\mathbf{2}$ & $\begin{array}{c}\text { Good } \\
\text { adaptation }\end{array}$ & $5-15$ & $80-100$ & $\begin{array}{l}\text { Burial of a high percentage of earthworms in few minutes, } \\
\text { complete burial of all animals within 15 min }\end{array}$ & ON \\
\hline $\mathbf{3}$ & $\begin{array}{c}\text { Medium } \\
\text { adaptation }\end{array}$ & $<15$ & $50-80$ & $\begin{array}{l}\text { Burial of the majority of earthworms within 15 min, while } \\
\text { some others stay on the soil surface. Little suffering }\end{array}$ & OFF \\
\hline $\mathbf{4}$ & $\begin{array}{c}\text { Bad } \\
\text { adaptation }\end{array}$ & $<15$ & $0-50$ & $\begin{array}{l}\text { Burial of the minority of earthworms within 15 min, the } \\
\text { majority of the animals stay on the surface, some died. General } \\
\text { suffering }\end{array}$ & OFF \\
\hline $\mathbf{5}$ & $\begin{array}{c}\text { Very bad } \\
\text { adaptation }\end{array}$ & $<15$ & 0 & $\begin{array}{l}\text { None of the earthworms are able to bury themselves, death of } \\
\text { all animals within 15 min. Very high suffering }\end{array}$ & OFF \\
\hline
\end{tabular}


Pivato A., Vanin S., Raga R., Lavagnolo M.C., Barausse A., Rieple A., Laurent A., Cossu R. 2016. Use of digestate from a decentralized on-farm biogas plant as fertilizer in soils: An ecotoxicological study for future indicators in risk and life cycle assessment. Waste Management 49, 378-389. http://dx.doi.org/10.1016/j.wasman.2015.12.009.

Table 6. Acute ON-OFF test responses for the Acute Earthworms Biossay (EAB). Responses "ON" or "OFF" indicate a good or bad quality of digestate based on the tendency of the earthworms to bury themselves in the soil. This behavioral effect has been classified into 5 classes as reported in table 5 .

\begin{tabular}{|c|c|c|c|c|}
\hline Digestate Concentration & Response & Class & Response & Class \\
\hline$[\%]$ & \multicolumn{2}{|c|}{ Replicate 1 } & Replicate 2 \\
\hline $\mathbf{0 . 0}$ & ON & Class 1 & ON & Class 1 \\
\hline $\mathbf{2 . 5}$ & ON & Class 1 & ON & Class 1 \\
\hline $\mathbf{5 . 0}$ & ON & Class 1 & ON & Class 1 \\
\hline $\mathbf{7 . 5}$ & ON 1 & ON & Class 1 \\
\hline $\mathbf{1 0 . 0}$ & ON & Class 2 & ON & Class 2 \\
\hline $\mathbf{1 5 . 0}$ & ON & Class 2 & OFF & Class 2 \\
\hline $\mathbf{2 0 . 0}$ & ON & Class 3 3 & Class 3 \\
\hline $\mathbf{4 0 . 0}$ & OFF & OFF & Class 3 \\
\hline $\mathbf{7 0 . 0}$ & OFF & Class 4 & OFF & Class 4 \\
\hline $\mathbf{1 0 0 . 0}$ & OFF & Class 4 &
\end{tabular}


Pivato A., Vanin S., Raga R., Lavagnolo M.C., Barausse A., Rieple A., Laurent A., Cossu R. 2016. Use of digestate from a decentralized on-farm biogas plant as fertilizer in soils: An ecotoxicological study for future indicators in risk and life cycle assessment. Waste Management 49, 378-389. http://dx.doi.org/10.1016/j.wasman.2015.12.009.

Table 7. European assessment factors for soil compartment (extracted from EC, 2003)

\begin{tabular}{|c|c|}
\hline Available information & Assessment factor $^{a}$ \\
\hline $\begin{array}{l}\text { At least one L(E)C50 short-term toxicity test(s) } \\
\text { (e.g. plants, earthworms, or microorganisms) }\end{array}$ & 1000 \\
\hline NOEC for one long-term toxicity test & 100 \\
\hline $\begin{array}{l}\text { NOEC for long-term toxicity tests of two } \\
\text { trophic levels }\end{array}$ & 50 \\
\hline $\begin{array}{l}\text { NOEC for long-term toxicity tests for three } \\
\text { species of three trophic levels }\end{array}$ & 10 \\
\hline Species sensitivity distribution (SSD method) & $\begin{array}{l}5-1 \text {, to be fully justified on a } \\
\text { case-by-case basis }\end{array}$ \\
\hline Field data/data of model ecosystems & case-by-case \\
\hline
\end{tabular}


Pivato A., Vanin S., Raga R., Lavagnolo M.C., Barausse A., Rieple A., Laurent A., Cossu R. 2016. Use of digestate from a decentralized on-farm biogas plant as fertilizer in soils: An ecotoxicological study for future indicators in risk and life cycle assessment. Waste Management 49, 378-389. http://dx.doi.org/10.1016/j.wasman.2015.12.009.
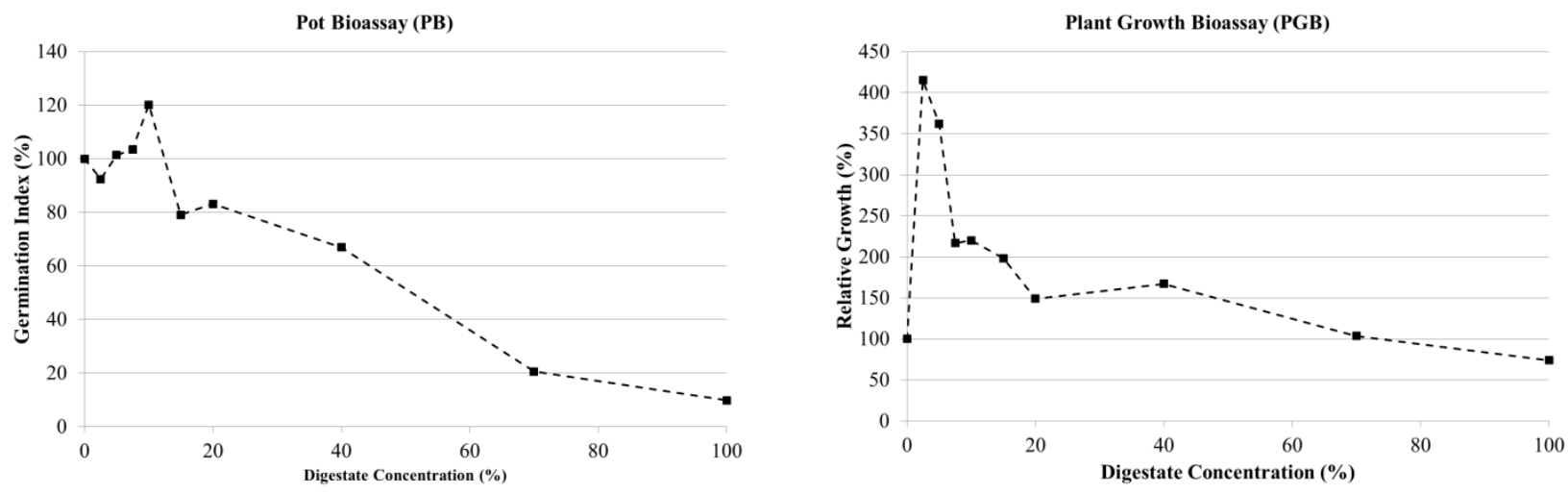

Substrate: $500 \mathrm{~g}$ of sand and peat $(1: 1 \mathrm{w} / \mathrm{w}), \mathrm{WHC}=70 \%$; Endpoint: Germination Index (GI)

Substrate: $500 \mathrm{~g}$ of sand and peat $(1: 1 \mathrm{v} / \mathrm{v}), \mathrm{WHC}=70 \%$; Endpoint: Relative Growth (RG)
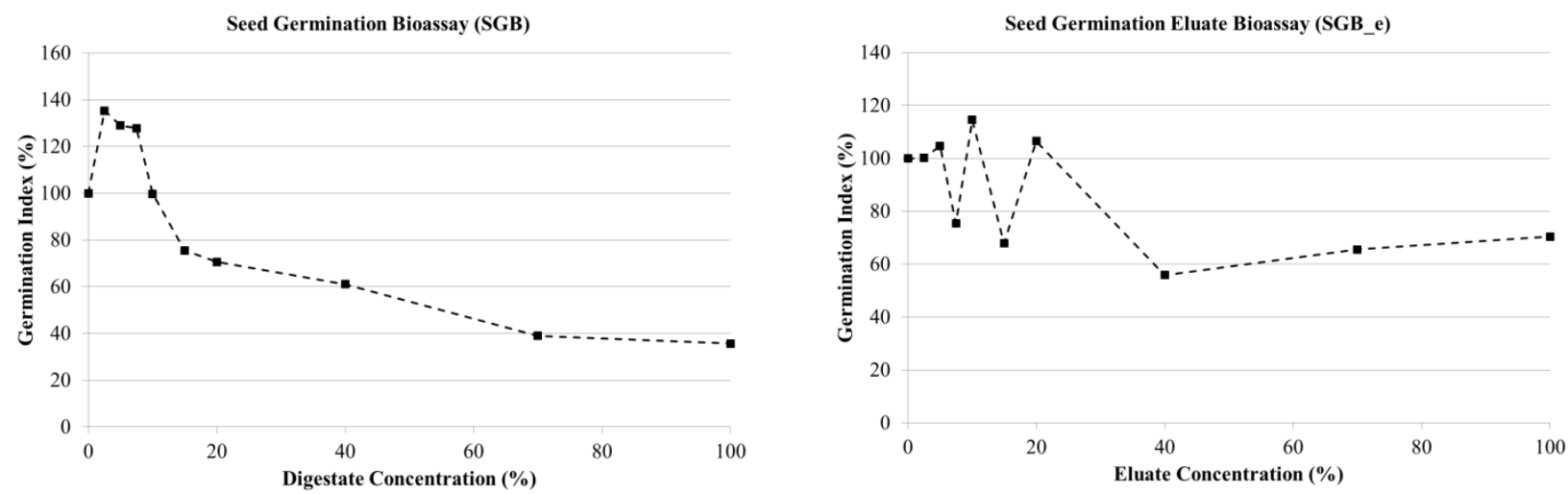

Substrate: $10 \mathrm{~g}$ of sand (WHC=100\%); Endpoint: Germination Index (GI)

Liquid-to-solid ratio (L/S) for eluate: 1:50, Media: water solution ; Endpoint: Germination Index (GI)

Figure 1. Results of the Plant Bioassays (Pot Bioassay, Plant Growth Bioassay, Seed Germination Bioassay, Seed Germination Eluate Bioassay) 
Pivato A., Vanin S., Raga R., Lavagnolo M.C., Barausse A., Rieple A., Laurent A., Cossu R. 2016. Use of digestate from a decentralized on-farm biogas plant as fertilizer in soils: An ecotoxicological study for future indicators in risk and life cycle assessment. Waste Management 49, 378-389. http://dx.doi.org/10.1016/j.wasman.2015.12.009.
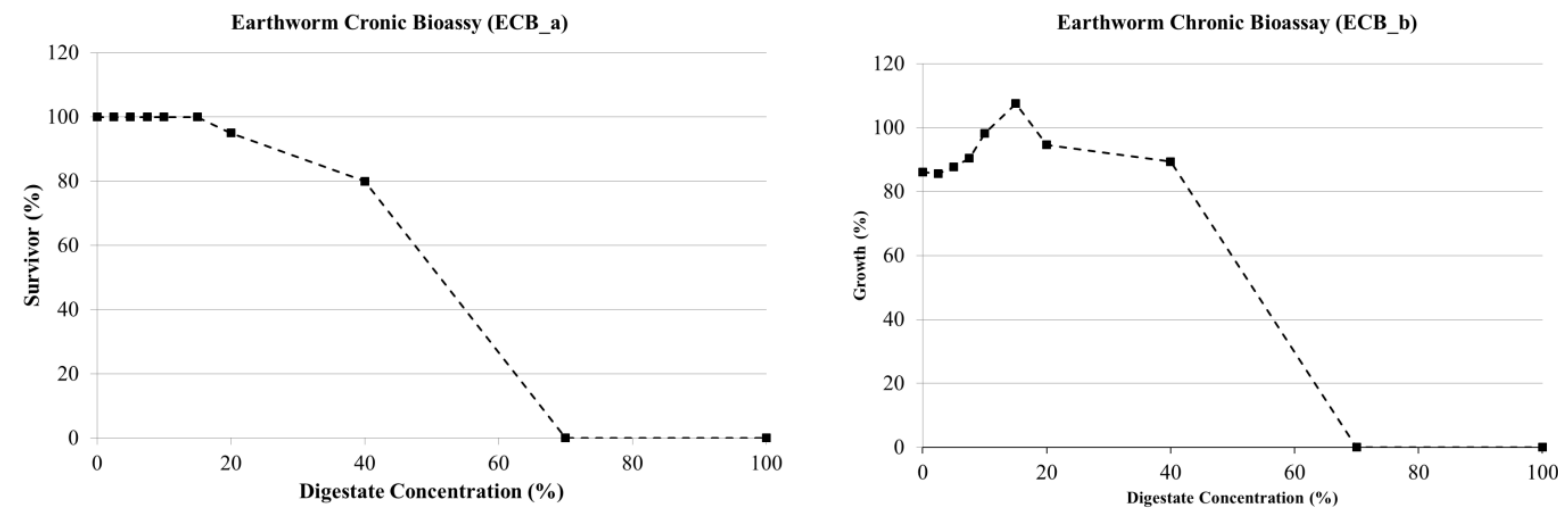

Substrate: 500 g of standard OECD soil; Endpoint: Survival (Su) Substrate: 500 g of standard OECD soil; Endpoint: Growth (Gr)

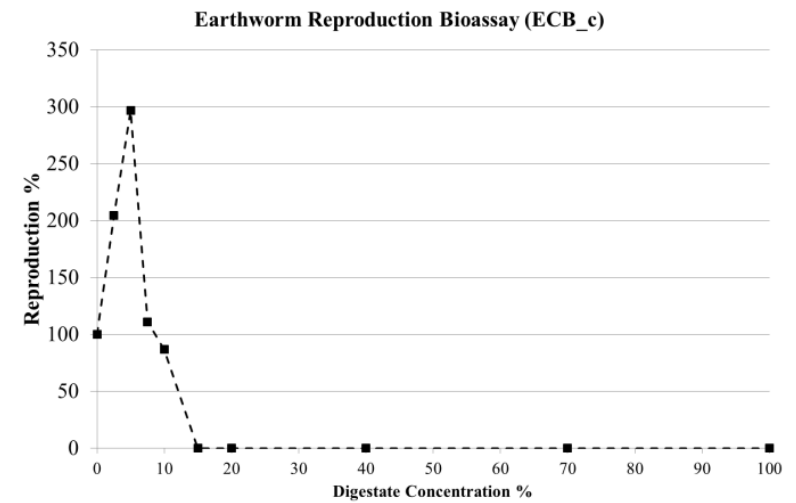

Substrate: $500 \mathrm{~g}$ of standard OECD soil; Endpoint: Reproduction (Re)

Figure 2. Results of the Earthworm Chronic Bioassay 
Pivato A., Vanin S., Raga R., Lavagnolo M.C., Barausse A., Rieple A., Laurent A., Cossu R. 2016. Use of digestate from a decentralized on-farm biogas plant as fertilizer in soils: An ecotoxicological study for future indicators in risk and life cycle assessment. Waste Management 49, 378-389. http://dx.doi.org/10.1016/j.wasman.2015.12.009.

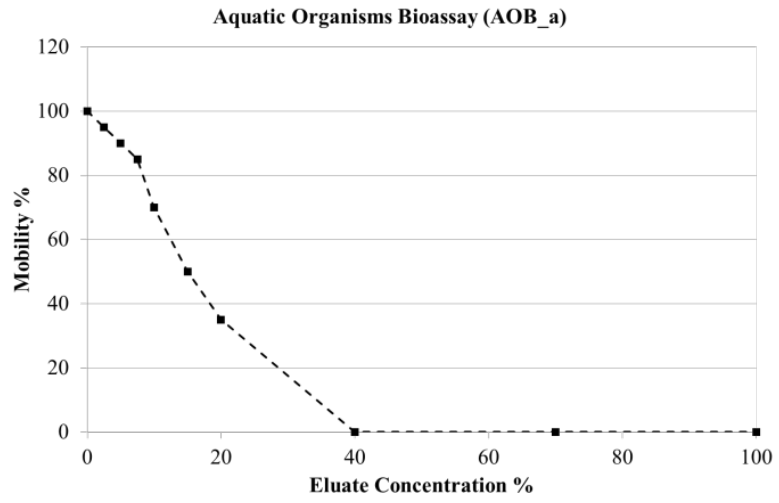

Figure 3. Results of the test on Daphnia magna 